\title{
27. PETROCHEMISTRY OF ABYSSAL OCEANIC BASALTS AND DOLERITES, AND THEIR SECONDARY ALTERATIONS, SITES 469, 470, 471, 472, 4731
}

\author{
V. I. Grechin, V. A. Eroshchev-Shak, and B. P. Zolotarev, Geological Institute \\ of the U.S.S.R. Academy of Sciences, Moscow, U.S.S.R.
}

\section{INTRODUCTION}

This paper focuses on petrochemical properties of basalts and their secondary alterations. Eleven holes were drilled along the California and Baja California margin during Deep Sea Drilling Project Leg 63. Basement rocks were penetrated at five sites: $469\left(32^{\circ}\right.$ $\left.37.00^{\prime} \mathrm{N}, \quad 120^{\circ} 32.90^{\prime} \mathrm{W}\right), \quad 470 \quad\left(28^{\circ} 54.46^{\prime} \mathrm{N}, \quad 117^{\circ}\right.$ $\left.31.11^{\prime} \mathrm{W}\right), 471\left(23^{\circ} 28.93^{\prime} \mathrm{N}, 112^{\circ} 29.78^{\prime} \mathrm{W}\right), 472\left(23^{\circ}\right.$ $\left.00.35^{\prime} \mathrm{N}, 113^{\circ} 59.71^{\prime} \mathrm{W}\right)$, and $473\left(20^{\circ} 57.92^{\prime} \mathrm{N}, 107^{\circ}\right.$ $\left.03.81^{\prime} \mathrm{W}\right)$.

On the basis of shipboard petrographic work, some of the volcanic rocks were described as basalts, others as dolerites. The latter cannot be unequivocally attributed to effusive flows. The formation of dolerites is more likely related to intrusion of thin sills or dikes. Determining the age of these rocks by means of paleontological identifications of microfauna in overlying deposits is therefore a problem. Basalts and dolerites penetrated in Hole 469 were paleontologically assigned to the early Miocene, basalts of Holes 470 and 472 and dolerites of Hole 472 to the middle Miocene, and basalts and dolerites of Hole 473 to the late Miocene. Using chemical data, it is possible to classify some of these igneous rocks as oceanic tholeiites, others as alkalineolivine basalts. The nature of secondary alterations of basalts probably stems from hydrothermal processes rather than halmyrolysis. Alkaline-olivine basalts that were developed directly near the continental slope (Sites 469 and 471) are most favorable for postmagmatic transformations.

\section{METHODS}

In addition to the petrographic study of rocks in thin sections and shipboard data, chemical analyses were performed by the standard method of wet chemistry. X-ray analyses were made of the $0.001-\mathrm{mm}$ fraction, and K-feldspars were separated from crushed samples. We also employed microsounding, scanning electron microscope, infrared (IR) spectroscopy, and thermal analysis.

All chemical analyses of samples were done by chemists G. F. Galkovskaya, N. L. Kalashnikova, G. I. Karaseva, and V. F. Rychkova in the chemical-analytical laboratory of the Geological Institute of the U.S.S.R. Academy of Sciences in accordance with the laboratory techniques described in Zolotarev et al. (1979).

In order to obtain comparable data on the chemical composition of rocks that underwent different degrees of secondary alteration, the chemical analyses were recalculated by Barth's method (1948) to the constant amount of oxygen atoms equal to 1600 (Chetverikov, 1956). In some the results of chemical analyses were recalculated to the

\footnotetext{
${ }^{1}$ Initial Reports of the Deep Sea Drilling Project, Volume 63.
}

volume weight of rocks and represented in $\mathrm{g} / \mathrm{cm}^{3}$. The last method enables the most objective analysis of the migration ability of some chemical elements in secondary alterations of rocks.

Identification of secondary minerals was carried out by methods of X-ray diffraction using a Soviet device DROP-2 (which employs $\mathrm{CuK}$ radiation at $34 \mathrm{kv}$ and $20 \mathrm{~mA}$ with a scanning rate of $2 \% \mathrm{~min}$ ). The chemical compositions of some minerals in thin sections were determined by a French microsound (microprober) Cameca. In addition to the optical petrographic method, the character of mineral separates was studied on an English scanning electron microscope Cambridge Stereoscope-600. For characterizing some minerals we studied curves of heating and differentiation curves of the weight loss obtained on a Hungarian derivatograph MOM. Infrared spectra of some secondary minerals were studied with the help of a Zeiss-Jena IR-20 spectrometer.

\section{RESULTS AND DISCUSSION}

\section{Petrochemistry of Basalts and Dolerites}

A geologic-petrochemical classification of volcanic rocks recovered during Leg 63 is rather difficult to attempt due to intense secondary alterations of these rocks. In some cases, however, because of the presence of glassy zones, porosity, and peculiarities of microstructure of the groundmass (variolitic, subvariolitic, hyalopilitic, and microhyaloporphyritic) these rocks can be reliably attributed to underwater eruptions resulting in formation of pillow-lavas (Sites 470, 472, and the lower parts of the base of Sites 469 and 473). In contrast, crystalline basalts without glassy zones are characterized by subophitic, ophitic, or intersertal textures peculiar to dolerites, and the character and degree of secondary alterations are similar to diabase. These rocks cannot be attributed unequivocally to underwater eruptions; more likely they represent intrusions of thin sills or subhorizontal dikes (Site 471 and upper parts of the base of Sites 469 and 473). Determining the age of these rocks by means of microfauna from overlying sediments is problematic. However, the absence of chilled contacts between diabases and enclosing sediments do not allow us to be sure of this assumption.

Petrographically and texturally, the basalts recovered in Holes $469,470,472$, and 473 are rather similar. These are principally aphyric basalts with small amounts of microphenocrysts of olivine and plagioclase sometimes forming glomeroporphyritic growths. The amount of plagioclase microphenocrysts is $1 \%$ to $3 \%$ and that of olivine, up to $1 \%$; their dimensions are from 0.02 to 0.7 $\mathrm{mm}$ (in rare cases, over $1 \mathrm{~mm}$ ). Olivine is commonly replaced by secondary minerals (smectite-celadonite, iddingsite, rarely carbonate). Porosity varies from $1 \%$ to $7 \%$. Pores are filled with smectite. Sometimes smectite 
covers the inner surface of vesicles, and their centers are filled with calcite. The structure of the groundmass is diverse, but most frequently it is subvariolitic and sometimes intergranular. In glassy zones it is subvariolitic, variolotic, and hyalopilitic. The content of ore component is $3 \%$ to $7 \%$. It is represented most frequently by ore dust or small xenomorphic patches. The groundmass of the rock is composed of plagioclase laths and clinopyroxene. Basalts are commonly crushed, being strongly carbonitized in the fracture zones. Dolerites are characterized by even grain size. These are mostly aphyric, sometimes with glomeroporphyritic patches of elongated crystals of plagioclase, clinopyroxene and olivine. They are often entirely replaced by secondary minerals (chlorite, smectite). Their structure is subophitic, less frequently intersertal, sometimes ophitic or glomeroporphyritic. The groundmass is composed of laths of plagioclase $(30-45 \%)$, clinopyroxene (up to $30 \%$ ), ore mineral $(7-10 \%)$, rarely amphibole. The secondary minerals are represented by smectite, chlorite, carbonate; mica and quartz also occur.

The results of complete silicate analyses of magmatic rocks are given in Table 1. The data obtained were used for compilation of two-component variation diagrams for the main rock-forming elements and some petrochemical coefficients. The MacDonald diagram in Figure 1 shows that the greater part of basalts can be assigned to the tholeiitic type, and only dolerites of Sites 469 and 471 are in the field of alkaline-olivine basalts. The quantitative ratios of some rock-forming elements $\left(\mathrm{MgO} / \mathrm{CaO}, \mathrm{Al}_{2} \mathrm{O}_{3} / \mathrm{CaO}, \Sigma \mathrm{FeO} / \mathrm{MgO}, \mathrm{Al}_{2} \mathrm{O}_{3} / \mathrm{MgO}\right.$, $\mathrm{Al}_{2} \mathrm{O}_{3} / \mathrm{TiO}_{2}$ ) also show by their chemistry that the basalts are mostly similar to the type of abyssal tholeiites widely distributed in the ocean (Figs. 2-6). These diagrams show that maximum deviations in the chemical composition of rocks of the abyssal-tholeiite type are characteristic of dolerites of Holes 469 and 471. This is most clearly evident in the $\mathrm{K}_{2} \mathrm{O} / \mathrm{TiO}_{2}$ diagram (Fig. 7). The ratios of these two elements in dolerites of Holes 469 and 471 are extremely close to analogous ratios established for tholeiites and alkaline basalts of arched volcanic uplifts of the Hawaiian type (Zolotarev, 1979). Dolerites of Site 473 differ from those of Sites 469 and 471 in that they are closer to basalts of Sites 470,472 , and 473 and to typical abyssal oceanic tholeiites when judged by all parameters. In the Miyashiro (1975) diagram, all the rocks studied are in the field of the primary composition (Fig. 8). The petrochemical differences between basalts and dolerites stem not so much from their degree of secondary alteration, but from the different chemistry of their primary magmas. Dolerites that differ significantly from abyssal oceanic tholeiites occur at Sites 469 and 471 , directly near the continental slope. This geological position appears to have determined the geochemical specialization of primary magmatic melts at these sites. Secondary transformation of basalts and dolerites in some cases resulted in certain compositional changes, namely, the relative increases of $\mathrm{MgO}$ and $\mathrm{K}_{2} \mathrm{O}$ contents and decreases of $\mathrm{SiO}_{2}, \mathrm{Al}_{2} \mathrm{O}_{3}$, and $\mathrm{CaO}$ contents. Thus we may conclude that epimagmatic transfor- mation of rocks proceeded without an appreciable inflow of chemical components.

\section{Alteration of Basalts and Dolerites}

\section{Hole 469}

Hole 469 penetrated dolerites at sub-bottom depths from 368.5 to 387.0 meters, and basalts at depths from 390.7 to 451.3 meters. Sedimentary rocks occur between them (in the interval from 369.0-390.7 m). Dolerites (Samples 469-40-1, 30-32, 469-41-1, 7-10, 469-42-5, 115-120) have ophitic and intersertal textures consisting of randomly distributed laths and phenocrysts of plagioclase. The matrix is replaced by clay minerals representing several generations. First, clay minerals replace all dark-colored minerals, such as pyroxenes and olivine, forming pseudomorphs after them. Second, clay minerals form large fanlike aggregates at the expense of interstitial glass. Third, clay minerals form small, slightly polarizing masses developed by alteration of small pyroxene patches. Aggregates of a small, poorly recrystallized clay mineral are fringed by a rim of coarser, well-polarizing clay mineral that lines vesicles in these rocks. Plagioclases are, as a rule, slightly altered. Clay minerals corrode plagioclase crystals and develop along fissures and cleavages.

X-ray diffractometry (XRD) demonstrates that clay minerals are smectites. An air-dried sample shows a strong basal reflection with $d=14.54 \AA$. After saturation with glycerine, the mineral yields basal reflections with $d=17.89 \AA, 15.54 \AA, 9.001 \AA, 4.52 \AA, 3.59 \AA$, $2.99 \AA$. After heating at $550^{\circ} \mathrm{C}$ a reflection with $d=$ $9.76 \AA$ is the major XRD peak. The analysis of diffractograms shows that the principal clay mineral is a mixed-layer phase consisting of $85 \%$ smectitic and $15 \%$ micaceous layers. Smectitic layers belong to highly ferruginous and magnesian varieties and are responsible for the appearance of a reflection with $d(060)=$ $1.531 \AA$. The X-ray data allow us to assert that there is no independent hydromica phase in these rocks (Fig. 9).

The chemical composition of dolerite is given in Table 1. The chemical composition of dolerites at Site 469 recalculated by the Barth (1948) method follows.

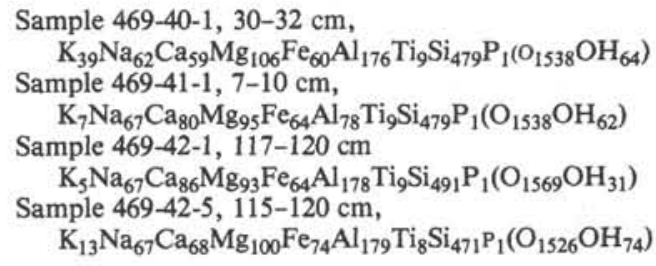

The degree of secondary alteration of dolerites is rather different. Petrographically, the least altered rock corresponds to Sample 469-42-1, 117-120 cm. This rock is characterized by a minimum $\mathrm{OH}$ content, recalculated after the Barth method. The examination of all altered dolerites relative to this rock allowed us, on the basis of the K-content, to distinguish two horizons bordering overlying and underlying sedimentary rocks. A similar 
trend is observed in the $\mathrm{Mg}$ content. These horizons are characterized by maximum secondary alterations of the rocks. It follows from the analysis of the balance of chemical elements in the profile of altered dolerites that in the course of alteration a relative increase of $\mathrm{K}$ and $\mathrm{Mg}$ contents (and in some cases that of $\mathrm{Fe}$ content) and a decrease of $\mathrm{Ca}, \mathrm{Al}$, and $\mathrm{Si}$ contents take place. The rest of the chemical elements are not distinctly differentiated during alteration of dolerites (Table 2). In the mixed-layer clays, potassium appears to be concentrated in the micaceous layers, whereas magnesium and iron, reside in the smectitic parts.

Basalts occur below dolerites at a depth of 390.7 to 451.3 meters sub-bottom depth in Hole 469. The upper part of the basalt section (390.7-423.2 m) is composed of holocrystalline varieties and the lower part (423.2$451.3 \mathrm{~m}$ ) mostly of glassy varieties.

In completely crystalline basalts (samples from Cores $44,45,46,47)$, plagioclase laths are randomly distributed; small xenomorphic grains of pyroxenes, olivine, and dusty matter are arranged between the laths. Glass and vesicles can be observed in a rock. The texture of basalts is subvariolitic and intersertal. Interstitial glass is entirely altered by clay material. The majority of vesicles are filled with clay minerals. Fe-hydroxides of colloform structure frequently compose the peripheral parts of vesicles. Some vesicles contain accumulations of red brown ore material at their centers. The rock is crossed by veins, up to $1 \mathrm{~mm}$ thick, composed of radial aggregates of a clay mineral. Red brown ore minerals of colloform structure are arranged along selvage veins. The vesicles situated near the veins are filled with clay minerals; those situated far from the veins are empty or lined with clay minerals. Parts of the basalts composed of sideromelane glass are completely replaced by green clay minerals. In Sample 469-45-1, 3-9 cm, vesicles and pores remain hollow. This rock is less altered by secondary processes.

In the X-ray diffractograms, the clay mineral in an air-dried state has a reflection with $d=14.30 \AA$. Upon saturation with glycerine, the mineral expands and yields reflections with $d=17.89 \AA, 8.97 \AA, 3.57 \AA$. After heating at $550^{\circ}$, it contracts to $9.77 \AA$ (Fig. 9). According to the X-ray studies, a clay mineral is a mixed-layer aggregate consisting of smectitic and few (up to $10 \%$ ) micaceous layers.

The chemical composition of the altered basalts is on the whole similar. Formula compositions of these basalts (after Barth, 1948) are presented in the following list.

\footnotetext{
Sample 469-44-1, 3-8 cm,

$\mathrm{K}_{5} \mathrm{Na}_{57} \mathrm{Ca}_{107} \mathrm{Mg}_{110} \mathrm{Fe}_{110} \mathrm{Al}_{166} \mathrm{Ti}_{15} \mathrm{Si}_{476} \mathrm{P}_{1}\left(\mathrm{O}_{1566} \mathrm{OH}_{34}\right)$ Sample 469-44-2, 110-113 cm,$$
\mathrm{K}_{7} \mathrm{Na}_{48} \mathrm{Ca}_{102} \mathrm{Mg}_{111} \mathrm{Fe}_{112} \mathrm{Al}_{164} \mathrm{Ti}_{14} \mathrm{Si}_{472} \mathrm{P}_{1}\left(\mathrm{O}_{1547} \mathrm{OH}_{53}\right)
$$$$
\text { Sample 469-45-1, 3-9 cm, }
$$$$
\mathrm{K}_{7} \mathrm{Na}_{55} \mathrm{Ca}_{92} \mathrm{Mg}_{93} \mathrm{Fe}_{108} \mathrm{Al}_{162} \mathrm{Ti}_{15} \mathrm{Si}_{465} \mathrm{P}_{1}\left(\mathrm{O}_{1542} \mathrm{OH}_{58}\right)
$$$$
\text { Sample 469-45-2, 11-7 cm, }
$$$$
\mathrm{K}_{5} \mathrm{Na}_{50} \mathrm{Ca}_{104} \mathrm{Mg}_{105} \mathrm{Fe}_{84} \mathrm{Al}_{166} \mathrm{Ti}_{14} \mathrm{Si}_{465} \mathrm{P}_{1}\left(\mathrm{O}_{1555} \mathrm{OH}_{45}\right)
$$$$
\text { Sample 469-46-1, 134-138 cm, }
$$$$
\mathrm{K}_{12} \mathrm{Na}_{59} \mathrm{Ca}_{68} \mathrm{Mg}_{80} \mathrm{Fe}_{114} \mathrm{Al}_{163} \mathrm{Ti}_{16} \mathrm{Si}_{444} \mathrm{P}_{2}\left(\mathrm{O}_{1512} \mathrm{OH}_{88}\right)
$$$$
\text { Sample 469-47-3, 86-92 cm, }
$$$$
\mathrm{K}_{6} \mathrm{Na}_{51} \mathrm{Ca}_{98} \mathrm{Mg}_{93} \mathrm{Fe}_{116} \mathrm{Al}_{153} \mathrm{Ti}_{15} \mathrm{Si}_{461} \mathrm{P}_{1}\left(\mathrm{O}_{1555} \mathrm{O}_{45}\right)
$$

The largest amount of potassium was observed in Sample 469-46-1, 134-138 cm. This rock is distinguished by maximum secondary alteration characterized by clay minerals and calcite. In the rest of the samples, the formation of the same secondary minerals takes place, but on a somewhat smaller scale. In our case, potassium, was well as the $\mathrm{OH}$ group, is evidence of considerable development of clay minerals represented by mixed-layer mica-smectites admixed by a small amount of micaceous layers. While analyzing the balance of chemical elements and new formation of secondary minerals, it becomes obvious that an insignificant increase of potassium content, and in some cases of $\mathrm{Fe}$ contents, takes place here. A relative decrease of $\mathrm{Na}$, $\mathrm{Ca}, \mathrm{Mg}, \mathrm{Al}$, and $\mathrm{Si}$ contents is observed (Table 3). On the whole, the negative balance of most of the chemical elements testifies to the processes of dissolution of rockforming minerals. The maximum alterations in basalts are associated with fractures and microfissures that served as canals for migration of solutions. In fractured rocks the pores, vesicles, and microfissures are filled with clay minerals. Newly formed smectitic minerals appear to concentrate potassium. Interestingly, the volume weight of $\mathrm{K}_{2} \mathrm{O}$ in basalts of various degrees of alteration along the profile is constant at $0.01 \mathrm{~g} / \mathrm{cm}^{3}$ (Table 1), which suggests that potassium participating in formation of mixed-layer minerals is not added from an outside source.

Below 423.2 meters in Hole 469, hyalobasalts prevail (samples from Cores 48, 49, 50, and 51). Hyalobasalts are composed of sideromelane volcanic glass-a product of underwater chilling of a basaltic melt. The glass is greenish brown, pierced by fine fissures having no definite orientation. Patches of colloform ore mineral can be observed within the glass. Intense red brown pigmentation is observed in microfissures. Unaltered glass is entirely isotropic. In the upper part of the section of hyalobasalts, the glass is completely replaced by clay minerals. Two types of clay-mineral isolation can be suggested. The first is frontal development of a clay mineral; the mechanism of its formation seems to be related to dissolution of glass and crystallization of a clay mineral (Fig. 10, A). The second is the filling of fissures with clay minerals (Fig. 10, C). Clay minerals form radial aggregates consisting of elongated and platy crystals. Under a scanning electron microscope, the aggregates of a clay mineral are visible as pyramids, the bases of which are oriented perpendicularly to the plane 001 . Some clay-mineral crystals display unevenly deformed lamellae. More deformed parts of the crystal are located at the base of an aggregate and less deformed ones at the top. This effect is responsible for narrowing of the aggregates toward the tops, thus the pyramidal morphology of the aggregates. Separate crystals are uneven plates (Fig. 10, B). Platy minerals develop in fissures in the glass. They form aggregates that are "firtree" in shape, with the top resting against the face of a fissure (Fig. 10, C). Among aggregates of clay minerals there are patches of a colloform ore mineral. In places within the clay mass, areas of undissolved glass are observed. 
Table 1. Chemical composition of magmatic rocks, Leg 63 .

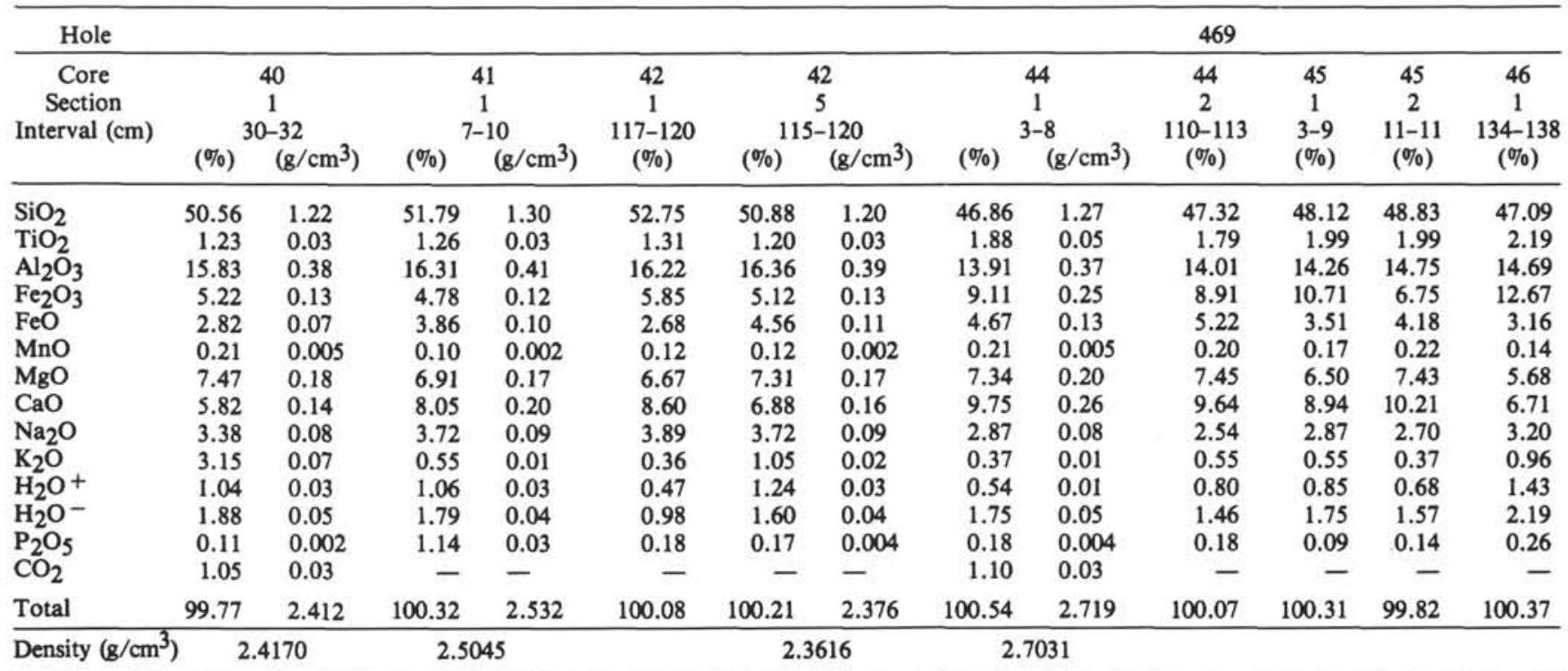

The glass of hyalobasalts is crystallized unevenly. Holocrystallized areas (for instance, Sample 469-49-1, $84-88 \mathrm{~cm}$ ) and those consisting of finest microlites of plagioclase form the subvariolitic texture and are distributed within noncrystallized glass (Sample 469-51-1, $34-40 \mathrm{~cm})$.

In an X-ray diffractogram of air-dried sideromelane glass (Sample $469-48-1,22-28 \mathrm{~cm}$ ), there is a strong basal reflection with $d=14.21 \AA$. After saturation with glycerine a series of basal reflections appears in a diffractogram, the strongest with $d=17.8 \AA$. After heating at $550^{\circ}, d(001)$ decreases to $9.63 \AA$ (Fig. 11). The mineral has $d(060)=1.531 \AA$. From the diffraction data on Sample 469-48-1, 22-28 cm, both the dioctahedral $\mathrm{Fe}$-smectite and the trioctahedral $\mathrm{Mg}$-smectite are present (Fig. 9).

The chemical analysis of the $0.001 \mathrm{~mm}$ fraction of this sample shows high $\mathrm{Fe}$ and $\mathrm{Mg}$ contents. The content of the components is as follows (wt. \%): $\mathrm{SiO}_{2}-44.85$, $\mathrm{TiO}_{2}-1.38, \mathrm{Al}_{2} \mathrm{O}_{3}-9.41, \mathrm{Fe}_{2} \mathrm{O}_{3}-9.13, \mathrm{FeO}-2.54$, $\mathrm{MnO}-0.03, \mathrm{CaO}-2.13, \mathrm{MgO}-13.33, \mathrm{Na}_{2} \mathrm{O}-0.42$, $\mathrm{K}_{2} \mathrm{O}-0.70$, LOI -16.30 , the total being 100.22 .

It is interesting to compare the chemical compositions of rocks (recalculated after Barth, 1948), for samples having various degrees of secondary alteration.

Sample 469-48-1, 22-28 cm,

$\mathrm{K}_{7} \mathrm{Na}_{41} \mathrm{Ca}_{12} \mathrm{Mg}_{199} \mathrm{Fe}_{99} \mathrm{Al}_{105} \mathrm{Ti}_{14} \mathrm{Si}_{446} \mathrm{P}_{0}\left(\mathrm{O}_{1445} \mathrm{OH}_{155}\right)$ Sample 469-48-1, 49-53 cm

$\mathrm{K}_{11} \mathrm{Na}_{43} \mathrm{Ca}_{13} \mathrm{Mg}_{125} \mathrm{Fe}_{94} \mathrm{Al}_{141} \mathrm{Ti}_{12} \mathrm{Si}_{409} \mathrm{P}_{1}\left(\mathrm{O}_{1349} \mathrm{OH}_{251}\right)$

Sample 469-49-1, 84-88 cm,

$\mathrm{K}_{5} \mathrm{Na}_{57} \mathrm{Ca}_{97} \mathrm{Mg}_{110} \mathrm{Fe}_{92} \mathrm{Al}_{180} \mathrm{Ti}_{14} \mathrm{Si}_{475} \mathrm{P}_{1}\left(\mathrm{O}_{1580} \mathrm{OH}_{20}\right)$

Sample 469-50-2, 27-32 cm,

$\mathrm{K}_{5} \mathrm{Na}_{43} \mathrm{Ca}_{98} \mathrm{Mg}_{114} \mathrm{Fe}_{106} \mathrm{Al}_{154} \mathrm{Ti}_{13} \mathrm{Si}_{455} \mathrm{P}_{1}\left(\mathrm{O}_{1535} \mathrm{OH}_{65}\right)$

Sample 469-51-1, 34-40 cm,

$\mathrm{K}_{6} \mathrm{Na}_{60} \mathrm{Ca}_{49} \mathrm{Mg}_{152} \mathrm{Fe}_{94} \mathrm{Al}_{143} \mathrm{Ti}_{10} \mathrm{Si}_{454} \mathrm{P}_{1}\left(\mathrm{O}_{1498} \mathrm{OH}_{102}\right)$

If the composition of the least-altered hyalobasalt sample $(469-49-1,84-88 \mathrm{~cm})$ is taken as characteristic of an unaltered rock, the degree of rock alteration will be shown by the balance of chemical elements listed in Table 4.

Formation of secondary minerals represented by smectite was accompanied by hyalobasalts by a relative decrease of $\mathrm{Na}, \mathrm{Ca}, \mathrm{Al}, \mathrm{Ti}$, and $\mathrm{Si}$ contents, and an increase of $\mathrm{K}$ and $\mathrm{Mg}$ contents. Hydration of rocks by a higher content of the $\mathrm{OH}$ group (after Barth, 1948) was recorded.

Thus at Site 469 , volcanic rocks belonging to two different groups were penetrated. Holocrystalline basalts and hyalobasalts belong to the abyssal tholeiites group. And dolerites belong to the alkaline-olivine basalts. Smectite formation in rocks of the first group develops mostly at the expense of sideromelane glass, and in the rocks of the second group-mostly at the expense of dark-colored minerals.

\section{Hole 470}

At a depth from 163 to 165 sub-bottom meters, Hole 470 penetrated basalts. The basalts are aphyric, with single microcrystals of plagioclase, and are characterized by subvariolitic texture. The rocks contain numerous vesicles and pores. Two types of secondary mineral development represented by clay complexes are established: (1) a clay mineral is crystallized in vesicles and pores, and; (2) clays replace olivine and partly replace pyroxene (Sample 470-18-2, 94-96 cm). In Sample $470-18-3,14-18 \mathrm{~cm}$, the subvariolitic texture of the groundmass is better developed; abundant pyroxene occurs in it. This rock contains much fewer vesicles and pores with secondary clay minerals. Some vesicles are filled with fresh glass. Areas and pores of calcite also occur. Clay minerals are developed after pyroxene.

The X-ray diffraction studies of clay minerals showed that they are a mixed-layer mineral consisting of smectite and micaceous layers, the content of micaceous layers not exceeding $10 \%$. Intensity and profile of basalt (001) reflection of minerals of these samples suggest that 
Table 1. (Continued).

\begin{tabular}{|c|c|c|c|c|c|c|c|c|c|c|c|c|c|c|}
\hline & & & & & & & \multicolumn{4}{|c|}{470} & \multicolumn{4}{|r|}{$470 \mathrm{~A}$} \\
\hline \multicolumn{2}{|c|}{$\begin{array}{c}47 \\
3 \\
86-92\end{array}$} & $\begin{array}{c}48 \\
1 \\
22-28 \\
(\%)\end{array}$ & $\begin{array}{c}48 \\
1 \\
49-53 \\
(\%)\end{array}$ & $\begin{array}{c}49 \\
1 \\
84-88 \\
(\%)\end{array}$ & $\begin{array}{c}50 \\
2 \\
27-32 \\
(\%)\end{array}$ & $\begin{array}{c}51 \\
1 \\
34-40 \\
(\%)\end{array}$ & $\begin{array}{c}7 \\
3 \\
127-132 \\
(\%)\end{array}$ & $\begin{array}{c}12 \\
1 \\
46-52 \\
(\%)\end{array}$ & $\begin{array}{c}18 \\
2 \\
94-96 \\
(\%)\end{array}$ & $\begin{array}{c}18 \\
3 \\
14-18 \\
(\%)\end{array}$ & $\begin{array}{c}7 \\
1 \\
108-113 \\
(\%)\end{array}$ & $\begin{array}{c}7 \\
2 \\
94-96 \\
(\%)\end{array}$ & $\begin{array}{c}8 \\
1 \\
20-26 \\
(\%)\end{array}$ & $\begin{array}{c}8 \\
5 \\
131-136 \\
(\%)\end{array}$ \\
\hline 47.74 & 1.33 & 46.10 & 44.60 & 48.34 & 47.26 & 47.53 & 48.39 & 48.11 & 49.29 & 48.91 & 48.95 & 47.82 & $48: 25$ & 48.27 \\
\hline 2.10 & 0.06 & 1.88 & 1.66 & 1.92 & 1.77 & 1.42 & 1.71 & 2.09 & 1.71 & 1.68 & 1.26 & 1.67 & 1.26 & 1.66 \\
\hline 13.52 & 0.37 & 9.24 & 13.06 & 15.61 & 13.61 & 12.91 & 15.61 & 14.79 & 14.10 & 14.27 & 15.80 & 13.72 & 13.81 & 13.92 \\
\hline 9.99 & 0.28 & 9.58 & 9.99 & 7.63 & 6.37 & 7.86 & 4.52 & 5.16 & 3.96 & 3.93 & 4.30 & 5.22 & 6.56 & 6.45 \\
\hline 5.05 & 0.14 & 3.58 & 3.17 & 4.03 & 7.18 & 4.49 & 5.00 & 4.87 & 6.31 & 5.58 & 4.73 & 5.30 & 4.61 & 4.73 \\
\hline 0.22 & 0.01 & 0.03 & 0.07 & 0.20 & 0.21 & 0.16 & 0.14 & 0.21 & 0.18 & 0.21 & 0.14 & 0.14 & 0.14 & 0.18 \\
\hline 6.47 & 0.18 & 13.84 & 9.20 & 7.53 & 7.96 & 10.67 & 6.14 & 6.72 & 6.91 & 6.89 & 7.61 & 9.34 & 6.82 & 7.33 \\
\hline 9.47 & 0.26 & 1.16 & 1.31 & 9.20 & 9.45 & 4.79 & 12.95 & 12.29 & 12.87 & 12.96 & 12.80 & 12.43 & 12.79 & 13.24 \\
\hline 2.70 & 0.07 & 2.20 & 2.37 & 3.04 & 2.34 & 3.15 & 2.87 & 2.94 & 1.98 & 2.08 & 2.18 & 2.37 & 2.70 & 2.70 \\
\hline 0.49 & 0.01 & 0.61 & 0.87 & 0.37 & 0.41 & 0.54 & 0.31 & 0.67 & 0.43 & 0.31 & 0.31 & 0.31 & 0.24 & 0.24 \\
\hline 0.74 & 0.04 & 4.22 & 4.13 & 0.29 & 1.00 & 1.59 & 1.02 & 0.78 & 0.99 & 1.90 & 0.93 & 0.82 & 1.00 & 0.71 \\
\hline 1.36 & 0.02 & 7.49 & 9.24 & 1.72 & 2.29 & 4.41 & 0.86 & 0.73 & 0.67 & 0.90 & 1.06 & 0.92 & 1.07 & 0.96 \\
\hline 0.14 & 0.004 & 0.03 & 0.08 & 0.16 & 0.16 & 0.18 & 0.11 & 0.26 & 0.13 & 0.08 & 0.12 & 0.15 & 0.12 & 0.10 \\
\hline- & - & - & - & - & - & - & - & - & - & - & - & - & - & - \\
\hline 99.99 & 2.774 & 99.96 & 99.75 & 100.04 & 100.01 & 99.60 & 100.28 & 99.62 & 99.53 & 99.70 & 100.19 & 100.21 & 99.49 & 100.49 \\
\hline \multicolumn{2}{|c|}{2.7810} & & & & & & & & & & & & & \\
\hline
\end{tabular}

the clay mineral in Sample 470-18-2, 94-96 cm is structurally less perfect than that in Sample 470-18-3, 14-18 cm (Fig. 11).

Table 1 presents the chemical composition of altered basalts in Hole 470. Analyses of these rocks recalculated after Barth (1948) show that in crystallization of clay minerals within vesicles and pores (Sample 470-18-2, 94-96 cm), the $\mathrm{K}$ and Si contents in the basalts are somewhat higher than in those clays replacing pyroxenes (Sample 470-18-3, 14-18 cm):

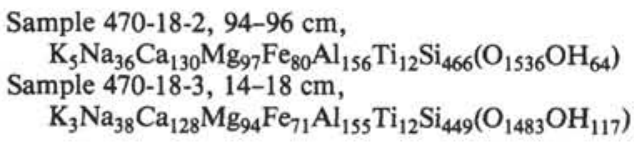

\section{Hole 470A}

Hole 470A penetrated basalts from 166.5 to 207.5 meters. In aphyric basalts (Sample 470A, 7-1, 108-113 $\mathrm{cm})$, the laths of plagioclase are oriented mostly in one direction; separate microphenocrysts of plagioclase sometimes form glomeroporphyritic clusters and vesicles. Dustlike patches of ore matter are widely distributed within the slightly recrystallized groundmass. In places there are areas composed of fresh glass. Sometimes the texture is pilotaxitic, less frequently subvariolitic. Finely crystalline patches of pyroxene and sporadic microphenocrysts of olivine are distributed within the groundmass. Clay minerals and calcite develop after glass. Vesicles are either hollow or filled with carbonate and, to a lesser extent, clay minerals. Vesicles are arranged in a rock in the form of a chain.

Downward in the section, the orientation of plagioclase laths is random (Sample 470A-7-2, 94-96 cm). Microphenocrysts of plagioclase and olivine and areas composed of glass can be observed as well. The groundmass of this rock consists of small crystals of pyroxene and plagioclase. Secondary clay minerals fill vesicles and replace interstitial glass or olivine. Clay minerals developed after pyroxene are much rarer.

Varieties of poorly recrystallized glass of subvariolitic texture (Sample 470A-8-1, 20-26 cm), as well as areas composed of nonrecrystallized sideromelane glass and some vesicles, are observed within basalts. Clay minerals in such pillow basalts develop after interstitial glass and, less frequently, after fissures in areas composed of glass; they also fill vesicles and pore space. Sometimes, most vesicles and pores in pillow lavas remain hollow, and plagioclases, pyroxenes, and interstitial glass are unaltered (Sample 470A-8-5, 131-136 $\mathrm{cm})$.

At sub-bottom depths of 183.5 to 191.0 meters, massive holocrystalline aphyric basalts consisting of plagioclase, pyroxene, and single olivine crystals occur. Plagioclases form large unoriented laths and glomeroporphyritic clusters. The groundmass contains aggregates of fine grains of plagioclase and pyroxene. Iron in olivines is partly oxidized and forms rims around crystals (Samples 470A-9-4, 104-106 cm and 470A-10-1, 49-55 cm). Glass fills microveins (Sample 470A-9-3, $117-119 \mathrm{~cm}$ ) and vesicles (Sample 470A-10-1, 104-111 $\mathrm{cm})$.

In the X-ray diffractograms, the clay minerals have first-order basalt reflections, with $d=13.94$ to 14.16 $\AA$. After saturation with glycerine the basalt reflection $d(001)$ becomes equal to 18.2 to $18.5 \AA$. After heating, the mineral contracts to $d=10 \AA$ (Fig. 12). The analysis of the X-ray diffraction data indicates that clay minerals are mixed-layer mica-smectite containing a few micaceous layers amounting roughly to $15 \%$. Smectitic layers are of ferruginous-magnesian composition.

The chemical composition of altered basalts in Hole 470A is rather similar (Table 1). The chemical formulas of rocks (after Barth, 1948) from samples having various secondary-alteration characteristics are as follows: 
Table 1. (Continued).

\begin{tabular}{|c|c|c|c|c|c|c|c|c|c|c|c|c|c|}
\hline \multicolumn{5}{|l|}{ Hole } & & & & & & & & & 471 \\
\hline $\begin{array}{c}\text { Core } \\
\text { Section } \\
\text { Interval }(\mathrm{cm})\end{array}$ & $\begin{array}{c}9 \\
3 \\
117-119 \\
(\%)\end{array}$ & $\begin{array}{c}9 \\
4 \\
104-106 \\
(\%)\end{array}$ & $\begin{array}{c}10 \\
1 \\
49-55 \\
(\%)\end{array}$ & $\begin{array}{c}10 \\
1 \\
104-111 \\
(\%)\end{array}$ & $\begin{array}{c}79 \\
1 \\
130-137 \\
(\%)\end{array}$ & $(\%)^{7}$ & $\begin{array}{l}80 \\
1 \\
8-84 \\
\left(\mathrm{~g} / \mathrm{cm}^{3}\right)\end{array}$ & \multicolumn{3}{|c|}{$\stackrel{2}{98-102}$} & $\begin{array}{c}81 \\
3 \\
59-65 \\
\left(\mathrm{~g} / \mathrm{cm}^{3}\right)\end{array}$ & $\begin{array}{r}8 \\
(\%)^{127}\end{array}$ & $\begin{array}{l}32 \\
1 \\
-132\end{array}$ \\
\hline $\mathrm{SiO}_{2}$ & 48.95 & 48.09 & 48.58 & 49.53 & 32.26 & 46.13 & 1.21 & 44.58 & 1.03 & 51.05 & 1.21 & 49.30 & 1.29 \\
\hline $\mathrm{TiO}_{2}$ & 1.69 & 1.69 & 1.27 & 1.67 & 1.70 & 2.30 & 0.06 & 2.13 & 0.05 & 1.87 & 0.04 & 1.27 & 0.03 \\
\hline $\mathrm{Al}_{2} \mathrm{O}_{3}$ & 15.00 & 13.99 & 14.06 & 14.28 & 11.84 & 14.03 & 0.37 & 13.61 & 0.31 & 14.72 & 0.35 & 14.11 & 0.37 \\
\hline $\mathrm{Fe}_{2} \mathrm{O}_{3}$ & 3.12 & 4.79 & 6.15 & 5.14 & 5.42 & 5.52 & 0.15 & 5.44 & 0.12 & 3.79 & 0.09 & 3.47 & 0.09 \\
\hline $\mathrm{FeO}$ & 5.86 & 4.99 & 4.60 & 5.13 & 5.78 & 5.53 & 0.15 & 6.39 & 0.15 & 5.38 & 0.13 & 7.19 & 0.19 \\
\hline $\mathrm{MnO}$ & 0.21 & 0.21 & 0.14 & 0.21 & 0.57 & 0.43 & 0.01 & 0.43 & 0.01 & 0.22 & 0.005 & 0.23 & 0.006 \\
\hline $\mathrm{MgO}$ & 7.73 & 7.19 & 7.16 & 6.00 & 5.32 & 10.07 & 0.26 & 12.57 & 0.29 & 6.12 & 0.14 & 8.78 & 0.23 \\
\hline $\mathrm{CaO}$ & 13.38 & 13.01 & 13.04 & 13.21 & 16.11 & 7.17 & 0.18 & 3.14 & 0.07 & 6.25 & 0.15 & 6.00 & 0.16 \\
\hline $\mathrm{Na}_{2} \mathrm{O}$ & 2.70 & 2.87 & 2.87 & 2.87 & 2.70 & 3.04 & 0.08 & 2.54 & 0.06 & 4.63 & 0.11 & 3.44 & 0.09 \\
\hline $\mathrm{K}_{2} \mathrm{O}$ & 0.12 & 0.24 & 0.24 & 0.12 & 0.42 & 0.49 & 0.01 & 1.76 & 0.04 & 2.44 & 0.06 & 2.44 & 0.06 \\
\hline $\mathrm{H}_{2} \mathrm{O}^{+}$ & 0.95 & 1.42 & 1.00 & 0.65 & 4.79 & 2.43 & 0.06 & 5.48 & 0.05 & 2.82 & 0.02 & 3.53 & 0.03 \\
\hline $\mathrm{H}_{2} \mathrm{O}^{-}$ & 0.75 & 0.99 & 0.99 & 0.74 & 1.00 & 2.18 & 0.06 & 2.24 & 0.13 & 0.82 & 0.07 & 1.04 & 0.09 \\
\hline $\mathrm{P}_{2} \mathrm{O}_{5}$ & 0.11 & 0.07 & 0.08 & 0.09 & 0.20 & 0.09 & 0.002 & 0.11 & 0.002 & 0.22 & 0.005 & 0.15 & 0.003 \\
\hline $\mathrm{CO}_{2}$ & - & - & - & - & 12.50 & - & - & - & - & - & - & - & - \\
\hline Total & 100.57 & 99.55 & 100.14 & 99.64 & 100.61 & 99.41 & 2.602 & 100.42 & 2.31 & 100.33 & 2.38 & 100.78 & 2.639 \\
\hline \multicolumn{5}{|c|}{ Density $\left(\mathrm{g} / \mathrm{cm}^{3}\right)$} & & \multicolumn{2}{|c|}{2.6176} & \multicolumn{3}{|c|}{2.3155} & 2.3676 & \multicolumn{2}{|c|}{2.6194} \\
\hline
\end{tabular}

Sample 470A-7-1, 108-113 cm, $\mathrm{K}_{3} \mathrm{Na}_{39} \mathrm{Ca}_{128} \mathrm{Mg}_{106} \mathrm{Fe}_{67} \mathrm{Al}_{174} \mathrm{Ti}_{9} \mathrm{Si}_{459} \mathrm{P}_{1}\left(\mathrm{O}_{1557} \mathrm{OH}_{63}\right)$ Sample 470A-7-2, 94-96 cm, $\mathrm{K}_{3} \mathrm{Na}_{45} \mathrm{Ca}_{126} \mathrm{Mg}_{132} \mathrm{Fe}_{81} \mathrm{Al}_{153} \mathrm{Ti}_{12} \mathrm{Si}_{455} \mathrm{P}_{1}\left(\mathrm{O}_{1550} \mathrm{OH}_{50}\right)$ Sample 470A-8-1, 20-26 cm, $\mathrm{K}_{2} \mathrm{Na}_{50} \mathrm{Ca}_{126} \mathrm{Mg}_{97} \mathrm{Fe}_{85} \mathrm{Al}_{154} \mathrm{Ti}_{9} \mathrm{Si}_{461} \mathrm{P}_{1}\left(\mathrm{O}_{1536} \mathrm{OH}_{64}\right)$ Sample 470A-8-5, 131-136 cm, $\mathrm{K}_{2} \mathrm{Na}_{50} \mathrm{Ca}_{135} \mathrm{Mg}_{104} \mathrm{Fe}_{86} \mathrm{Al}_{154} \mathrm{Ti}_{12} \mathrm{Si}_{461} \mathrm{P}_{1}\left(\mathrm{O}_{1555} \mathrm{OH}_{45}\right)$ Sample 470A-9-3, 117-119 cm, $\mathrm{K}_{1} \mathrm{Na}_{49} \mathrm{Ca}_{134} \mathrm{Mg}_{107} \mathrm{Fe}_{69} \mathrm{Al}_{165} \mathrm{Ti}_{12} \mathrm{Si}_{459} \mathrm{P}_{1}\left(\mathrm{O}_{1537} \mathrm{OH}_{63}\right)$ Sample 470A-9-4, 104-106 cm, $\mathrm{K}_{2} \mathrm{Na}_{53} \mathrm{Ca}_{131} \mathrm{Mg}_{101} \mathrm{Fe}_{79} \mathrm{Al}_{155} \mathrm{Ti}_{12} \mathrm{Si}_{452} \mathrm{P}_{1}\left(\mathrm{O}_{1512} \mathrm{OH}_{88}\right)$ Sample 470A-10-1, 49-55 cm, $\mathrm{K}_{9} \mathrm{Na}_{53} \mathrm{Ca}_{131} \mathrm{Mg}_{101} \mathrm{Fe}_{81} \mathrm{Al}_{156} \mathrm{Ti}_{12} \mathrm{Si}_{458} \mathrm{P}_{1}\left(\mathrm{O}_{1536} \mathrm{OH}_{64}\right)$ Sample 470A-10-1, 104-111 cm,

$\mathrm{K}_{1} \mathrm{Na}_{54} \mathrm{Ca}_{134} \mathrm{Mg}_{85} \mathrm{Fe}_{79} \mathrm{Al}_{160} \mathrm{Ti}_{12} \mathrm{Si}_{471} \mathrm{P}_{1}\left(\mathrm{O}_{1555} \mathrm{OH}_{45}\right)$

Basalts of Hole 470A approximately correspond to the average composition of basalts of the East Pacific Rise that are characterized by the formula $\mathrm{K}_{2} \mathrm{Na}_{57} \mathrm{Ca}_{118}$ $\mathrm{Mg}_{108} \mathrm{Fe}_{78} \mathrm{Al}_{186} \mathrm{Ti}_{11} \mathrm{Si}_{461} \mathrm{P}_{0}\left(\mathrm{O}_{1568} \mathrm{OH}_{32}\right)$ (recalculated after Barth, 1948).

The degree of alteration indicated by the secondary clay-mineral content allows us to conclude that all basalts of Hole 470A are approximately the same, differing only in the character of distinguishing secondary clay minerals. The components that form secondary clay minerals come from the alteration of primary minerals of the basalts, such as unstable sideromelane glass, olivine, and pyroxene. Clay minerals mostly replace interstitial glass and form pseudomorphs after dark-colored minerals or they crystallize from solutions enriched in components of the dissolved material within vesicles and fissures. Solutions circulating through basalts are the main agents of decomposition of these minerals.

Compared with the average composition of basalts of the East Pacific Rise, the altered basalts of Hole 470A are characterized by a greater degree of dehydration.
The enrichment of some horizons of these aphyric basalts with potassium suggests that an outside potassium source is unnecessary for formation of a small number of micaceous layers in mixed-layer mica-smectitic clay minerals.

\section{Hole 472}

Basalts were also penetrated in Hole 472 from 112 to 131 meters sub-bottom depth. At a depth of 112 to 115 meters, aphyric basalts are represented by massive varieties characterized by different degrees of crystallization. The basalts consist of plagioclase laths and single microphenocrysts of plagioclase with finely crystalline pyroxene crystals between them. Glass is observed in interstices. Vesicles and pores are frequent in the groundmass (Samples 472-14-1, 115-120 cm and $472-14-2,76-82 \mathrm{~cm})$. The basalts are slightly altered by secondary processes. Clay minerals develop after interstitial glass; along with carbonates they fill pores and vesicles. Vesicles are sometimes lined with calcite succeeded by clay minerals. Sample 472-15-1, 20-24 cm (depth $119.5 \mathrm{~m}$ ) is finely crystalline aphyric basalt with subvariolitic texture. There is more pyroxene than plagioclase in the groundmass. The rock is altered little by secondary processes. Pores and vesicles in basalts are empty.

Pillow basalts occur at a sub-bottom depth of 120.0 to 122.5 meters (Samples 472-15-1, 69-77 $\mathrm{cm}$ 472-15-2, $0-3 \mathrm{~cm}$ ) and contain small laths of plagioclase having no definite orientation. The groundmass is composed of small crystals of pyroxene, microlites of plagioclase, glass, and dustlike ore material. Some horizons of pillow basalts are intensely altered (Sample 472-15-1, 69-77 cm). In the lower part of the pillow basalts at a depth of 122 meters, the rocks are less altered (Sample $472-15-2,9-14 \mathrm{~cm})$. Vesicles and pores in these rocks are 
Table 1. (Continued).

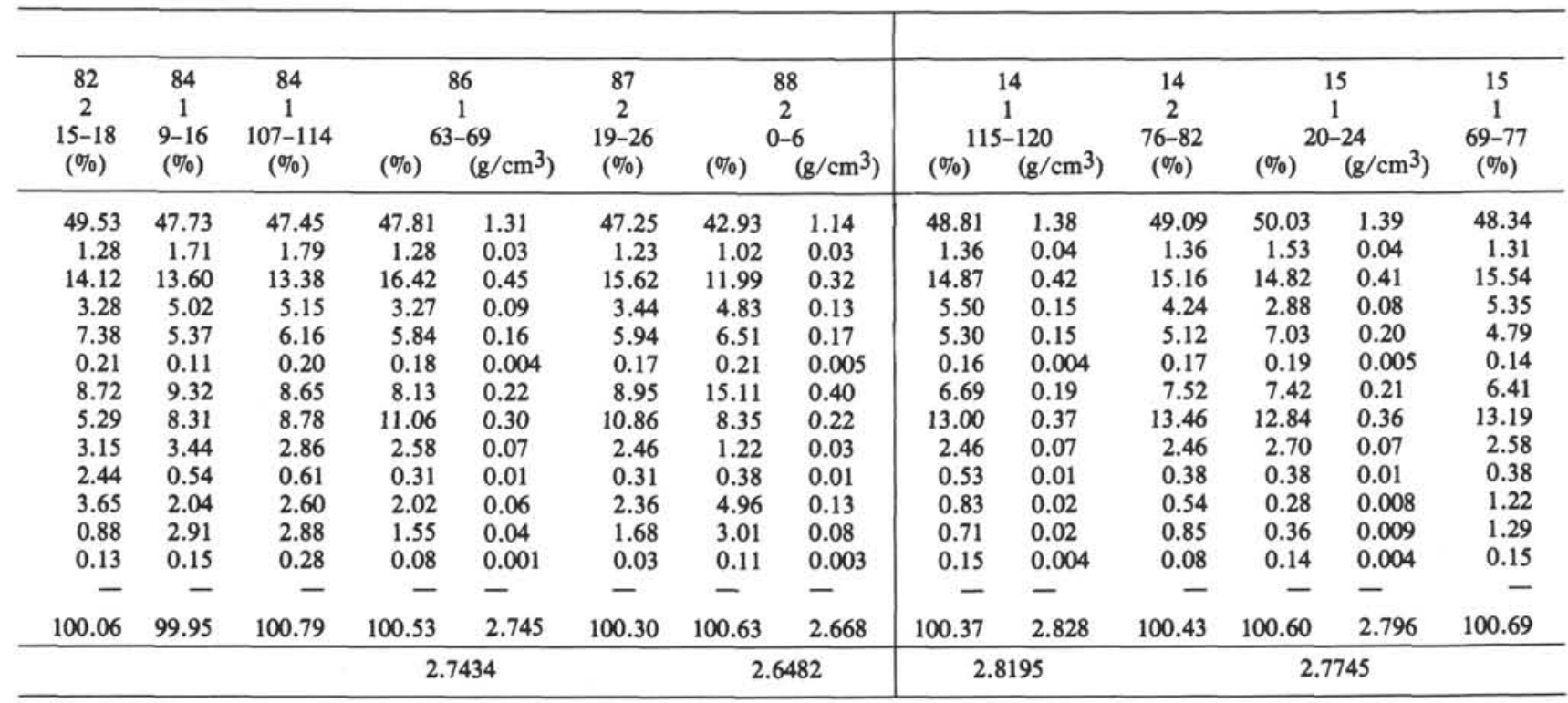

empty or only slightly incrusted with clay minerals. Clay minerals in these rocks are formed by alteration of interstitial glass.

Downward in the section, at depths from 122.5 to 131.0 meters (Samples 472-16-1, 12-15 cm 472-16-1, 83$89 \mathrm{~cm}, 472-16-1,145-150 \mathrm{~cm}$ ), finely crystalline aphyric basalts with subvariolitic textures are distributed. Microphenocrysts of plagioclase, pyroxene and olivine, sometimes forming glomeroporphyritic clusters, and numerous large vesicles are frequently found in these rocks. Basalts are strongly altered. Secondary products are clay minerals and carbonates. Clay minerals fill pores and vesicles, develop after interstitial glass, and replace olivine and, less frequently, pyroxene. Carbonate is localized near altered grains of pyroxene. Zeolites can sometimes be recognized in pores and fissures. The altered basalts are characterized by uneven development of secondary minerals. In one thin section, one can observe areas of different degrees of alteration. In the $\mathrm{X}$-ray diffractogram the clay minerals in an air-dried state have the first basal reflection with $d=13.9$ $14.7 \AA$. After saturation with glycerine, the minerals expand differently. After saturation with glycerine, Sample $472-14-1,115-120 \mathrm{~cm}$ is characterized by expanding up to $d=17.89 \AA$, basal reflections of lower order not being manifested. After heating at $550^{\circ} \mathrm{C}$, the first basal reflection had $d=10 \AA$. After both saturation with glycerine and heating, the profiles of reflections remain asymmetrical (Fig. 13), which indicates that clay minerals in Sample 472-14-1, 115-120 cm have heterogeneous compositions. An iron-rich mixed-layer clay consisting of smectitic and a few micaceous layers occurs here. In Sample 472-15-2, 0-3, a broad reflection of smectite after saturation with glycerine expands the value to $d=18.0 \AA$, and after heating at $550^{\circ} \mathrm{C}, d=$ $10 \AA$. Such a diffraction pattern is peculiar to finely dispersed, poorly crystallized ferruginous smectite. In addition, a disordered mixed-layered mineral containing smectitic and few micaceous layers may also be present. In Sample 472-16-1, 83-89 cm, besides poorly crystallized mixed-layer smectite-mica, there are small amounts of "imperfect" chlorite; this chlorite can be distinguished in diffractograms of a heated specimen by a weak reflection with $d=11.98 \AA$. A clay mineral in Sample 472-16-2, 94-99 cm is also imperfect; it shows a strong basal reflection of $d=13.9 \AA$ after treatment with glycerine. After heating at $550^{\circ} \mathrm{C}$, the reflection reduces to $10.05 \AA$. When this mineral is saturated with glycerine and heated, XRD peaks of the first basal reflection are asymmetrical. Proceeding from the analysis of alterations of interplanar spaces of the first-order basalt reflection and distribution of intensities for this reflection, one can assume that the clay mineral is represented by poorly crystallized, finely dispersed $\mathrm{Fe}$-smectite and a disordered, mixed-layer mica-smectite, with the micaceous layer up to $15 \%$ (Fig. 13).

These data demonstrate that basalts in Hole $\mathbf{4 7 2}$ are variously altered. Secondary, poorly crystallized clay minerals are best developed in basalts characterized by Samples 472-15-1, 69-77 cm, 472-16-1, 12-15 cm, $472-16-1,145-150 \mathrm{~cm}$, and $472-16-2,94-99 \mathrm{~cm}$.

The chemical compositions of Hole 472 basalts are uniform (Table 1). The following list shows chemical compositions of these basalts (recalculated after Barth, 1948), which have undergone various degrees of secondary mineral alteration.

Sample 472-14-1, 115-120 cm,

$\mathrm{K}_{6} \mathrm{Na}_{46} \mathrm{Ca}_{134} \mathrm{Mg}_{96} \mathrm{Fe}_{83} \mathrm{Al}_{168} \mathrm{Ti}_{10} \mathrm{Si}_{469} \mathrm{P}_{1}\left(\mathrm{O}_{1549} \mathrm{OH}_{51}\right)$ Sample 472-14-2, 76-82 cm,

$\mathrm{K}_{5} \mathrm{Na}_{46} \mathrm{Ca}_{138} \mathrm{Mg}_{106} \mathrm{Fe}_{72} \mathrm{Al}_{170} \mathrm{Ti}_{10} \mathrm{Si}_{467} \mathrm{P}_{1}\left(\mathrm{O}_{1568} \mathrm{OH}_{32}\right)$

Sample 472-15-1, 20-24 cm,

$\mathrm{K}_{5} \mathrm{Na}_{50} \mathrm{Ca}_{131} \mathrm{Mg}_{105} \mathrm{Fe}_{78} \mathrm{Al}_{166} \mathrm{Ti}_{11} \mathrm{Si}_{478} \mathrm{P}_{1}\left(\mathrm{O}_{1581} \mathrm{OH}_{19}\right)$

Sample 472-15-1, 69-77 cm,

$\mathrm{K}_{4} \mathrm{Na}_{47} \mathrm{Ca}_{132} \mathrm{Mg}_{89} \mathrm{Fe}_{76} \mathrm{Al}_{171} \mathrm{Ti}_{9} \mathrm{Si}_{452} \mathrm{P}_{1}\left(\mathrm{O}_{1525} \mathrm{OH}_{75}\right)$

Sample 472-15-2, 0-3 cm,

$\mathrm{K}_{6} \mathrm{Na}_{48} \mathrm{Ca}_{135} \mathrm{Mg}_{103} \mathrm{Fe}_{75} \mathrm{Al}_{168} \mathrm{Ti}_{10} \mathrm{Si}_{471} \mathrm{P}_{1}\left(\mathrm{O}_{1568} \mathrm{OH}_{32}\right)$

Sample 472-15-2, 9-14 cm,

$\mathrm{K}_{3} \mathrm{Na}_{46} \mathrm{Ca}_{132} \mathrm{Mg}_{108} \mathrm{Fe}_{77} \mathrm{Al}_{169} \mathrm{Ti}_{10} \mathrm{Si}_{471} \mathrm{P}_{1}\left(\mathrm{O}_{1580} \mathrm{OH}_{20}\right)$ 
Table 1. (Continued).

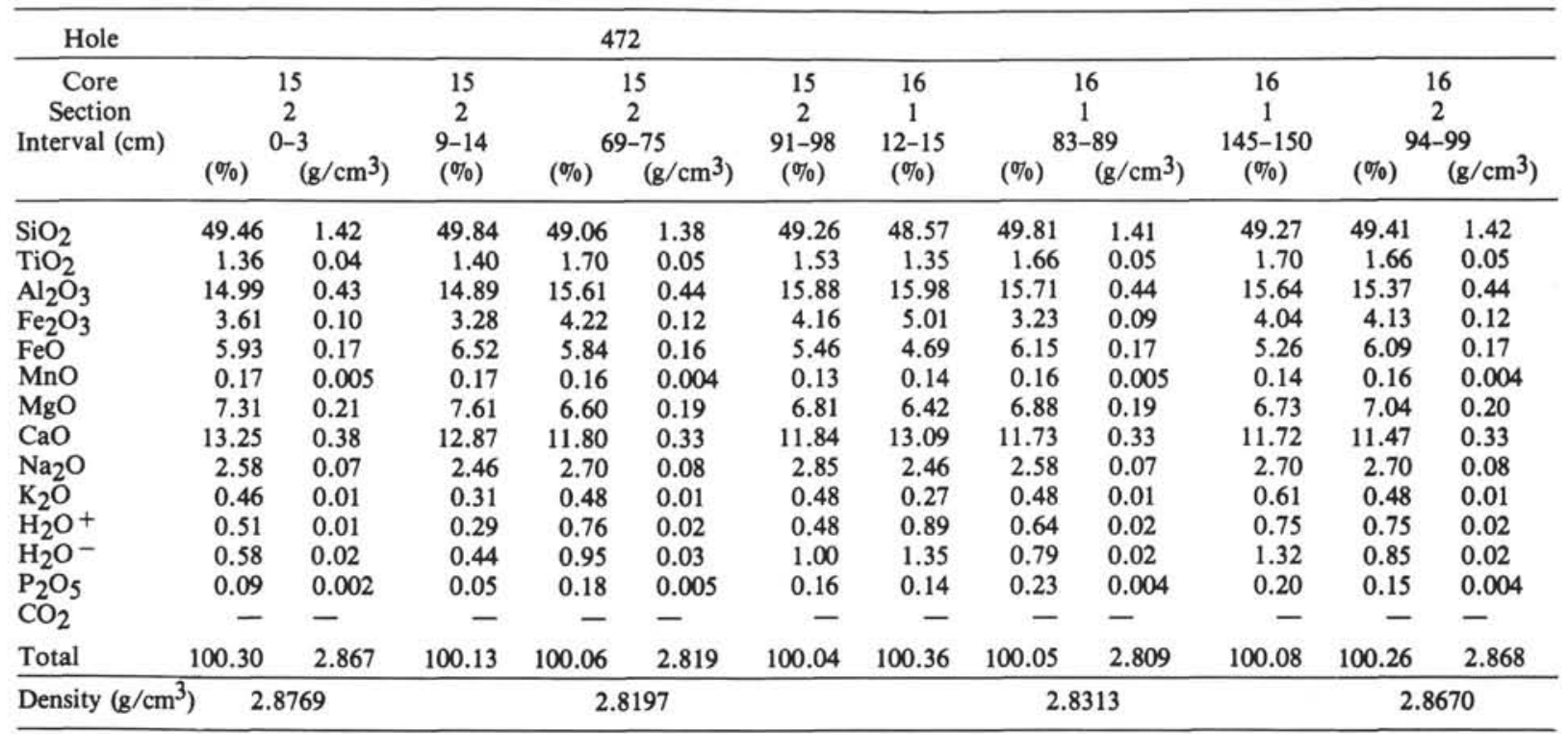

Sample 472-15-2, 69-75 cm, $\mathrm{K}_{6} \mathrm{Na}_{50} \mathrm{Ca}_{119} \mathrm{Mg}_{93} \mathrm{Fe}_{78} \mathrm{Al}_{174} \mathrm{Ti}_{12} \mathrm{Si}_{465} \mathrm{P}_{1}\left(\mathrm{O}_{1550} \mathrm{OH}_{50}\right)$ Sample 472-15-2, 91-98 cm, $\mathrm{K}_{6} \mathrm{Na}_{54} \mathrm{Ca}_{120} \mathrm{Mg}_{97} \mathrm{Fe}_{75} \mathrm{Al}_{178} \mathrm{Ti}_{11} \mathrm{Si}_{470} \mathrm{P}_{1}\left(\mathrm{O}_{1568} \mathrm{OH}_{32}\right)$ Sample 472-16-1, 12-15 cm, $\mathrm{K}_{3} \mathrm{Na}_{45} \mathrm{Ca}_{131} \mathrm{Mg}_{89} \mathrm{Fe}_{72} \mathrm{Al}_{186} \mathrm{Ti}_{10} \mathrm{Si}_{454} \mathrm{P}_{1}\left(\mathrm{O}_{1544} \mathrm{OH}_{56}\right)$ Sample 472-16-1, 83-89 cm,

$\mathrm{K}_{6} \mathrm{Na}_{48} \mathrm{Ca}_{119} \mathrm{Mg}_{97} \mathrm{Fe}_{74} \mathrm{Al}_{175} \mathrm{Ti}_{12} \mathrm{Si}_{471} \mathrm{P}_{1}\left(\mathrm{O}_{1563} \mathrm{OH}_{37}\right)$ Sample 472-16-1, 145-150 cm,

$\mathrm{K}_{7} \mathrm{Na}_{51} \mathrm{Ca}_{121} \mathrm{Mg}_{96} \mathrm{Fe}_{72} \mathrm{Al}_{176} \mathrm{Ti}_{12} \mathrm{Si}_{475} \mathrm{P}_{1}\left(\mathrm{O}_{1549} \mathrm{OH}_{51}\right)$ Sample 472-16-2, 94-99 cm,

$\mathrm{K}_{6} \mathrm{Na}_{50} \mathrm{Ca}_{116} \mathrm{Mg}_{98} \mathrm{Fe}_{79} \mathrm{Al}_{171} \mathrm{Ti}_{11} \mathrm{Si}_{466} \mathrm{P}_{1}\left(\mathrm{O}_{1550} \mathrm{OH}_{50}\right)$

Like previously analyzed basalts at Hole 469, 470, and $470 \mathrm{~A}$, basalts from Hole 472 show uneven development of secondary processses. Both slightly altered rocks (Sample 472-15-1, 20-24 cm) and intensely altered rocks occur. Table 5 presents data of the balance of chemical elements at various degrees of alteration in a section of Hole 472 relative to slightly altered rock represented by Sample 472-15-1, 20-24 cm.

Analysis of these data suggests that the formation of secondary clay minerals here is characterized by four types of geochemical processes. The first is a relative increase of $\mathrm{K}$ and $\mathrm{Fe}$ contents and decrease of $\mathrm{Mg}$ content in rocks. In this case the alteration of interstitial glass and dark-colored minerals result in formation of clay minerals. The mineral-forming solution is mobile, resulting in crystallization of clay minerals in vesicles and pores. Mixed-layer complexes consisting of Fe-smectite and a few micaceous layers are the principal clay minerals formed. Smectitic beds are dioctahedral and poor in magnesium (Samples 472-14-1, 115-120 cm, 472-16-2, 94-99 cm). The second type of geochemical process includes secondary mineral formation in the groundmass and accompanying increases of $\mathrm{K}$ and decreases of $\mathrm{Mg}$ and $\mathrm{Fe}$ contents. The clay minerals are finely dispersed, mixed-layer complexes composed of smectitic and a few micaceous layers (Samples 472-15-2, 0-3 cm, 472-15-2, 69-75 cm, 472-15-2, 91-98 cm, $472-16-1,83-89 \mathrm{~cm}, 472-16-1,145-150 \mathrm{~cm})$. The third type of geochemical process is characterized by a relative increase of $\mathrm{Mg}$ and decrease of $\mathrm{K}$ and $\mathrm{Fe}$ contents. If this process proceeds in holocrystalline basalts, the secondary minerals are formed through alteration of interstitial glass. The mobile, mineral-forming solution infiltrates into pores, vesicles, and fissures and is responsible for filling these spaces with clay minerals. In pillow basalts the clay minerals replace glass only, $\mathrm{Mg}$-smectite being predominant. However, altered rocks also contain mixed-layer, micaceous-smectitic complexes with a small amount of micaceous layers (Samples 472-14-2, $76-82 \mathrm{~cm}$ and $472-15-2,9-14 \mathrm{~cm}$ ). Finally, the fourth type of geochemical process is characterized by a relative decrease of $\mathrm{K}, \mathrm{Mg}$, and Fe contents, finely dispersed smectites being formed (Samples 472-15-1, 69-70 cm and $472-16-1,12-15 \mathrm{~cm})$. In general, several geochemical processes may operate simultaneously and some of these processes may themselves change in the alteration of basalts; the clay minerals formed are a summary result of these processes.

On the whole, holocrystalline basalts and pillow lavas in a section at Site 472 are characterized by: (1) uneven manifestations of secondary processes of rock alteration and, consequently, uneven development of clay minerals; (2) absence of vertical zonations of secondary mineral formation; (3) simultaneous formation of clay minerals and an increase of $\mathrm{Al}$ content and decrease of $\mathrm{Si}$ content in the basalts during intense hydration; and (4) variations of chemical composition of the basalts related to development of secondary clay mineral. After recalculation to volume weights of rocks, the $\mathrm{K}_{2} \mathrm{O}$ content in the pillow basalts is $0.01 \mathrm{~g} / \mathrm{cm}^{3}, \mathrm{MgO}=0.19$ $\mathrm{g} / \mathrm{cm}^{3}$ (except for Sample $472-15-2,0-3 \mathrm{~cm}$, where the $\mathrm{MgO}$ content is $\left.0.21 \mathrm{~g} / \mathrm{cm}^{3}\right)$. The $\mathrm{SiO}_{2}$ content varies from 1.38 to $1.42 \mathrm{~g} / \mathrm{cm}^{3}$, and that of $\mathrm{Al}_{2} \mathrm{O}_{3}$ from 0.42 to $0.44 \mathrm{~g} / \mathrm{cm}^{3}$. These data suggest isochemical secondary alteration of basaltic rocks at Hole 472. The amounts of chemical elements contained in unaltered rocks are suf- 
Table 1. (Continued).

\begin{tabular}{rrrrrrrrrr}
\hline \multicolumn{10}{c}{473} \\
\hline \multicolumn{10}{c}{29} \\
1
\end{tabular}

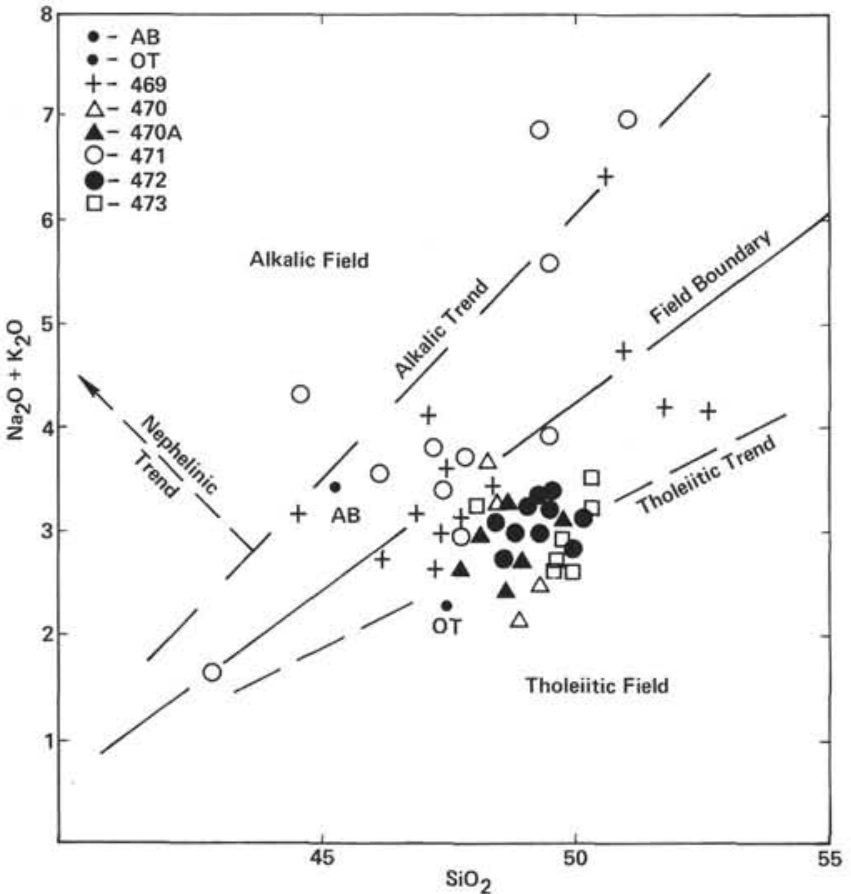

Figure 1. MacDonald diagram. $(\mathrm{AB}=$ composition of primary melts of alkaline-olivine basalts. OT = composition of primary melts of oceanic tholeiites.)

ficient for formation of secondary clay minerals in basalts and pillow lavas. The process of secondary mineral formation was characterized by insignificant redistribution of rock-forming chemical elements in a section. Their mobilization was probably accomplished by reaction with a low-mineralized thermal solution.

\section{Hole 473}

In Hole 473 the volcanic rocks were penetrated at sub-bottom depths from 247.5 to 287.4 meters. Petro-

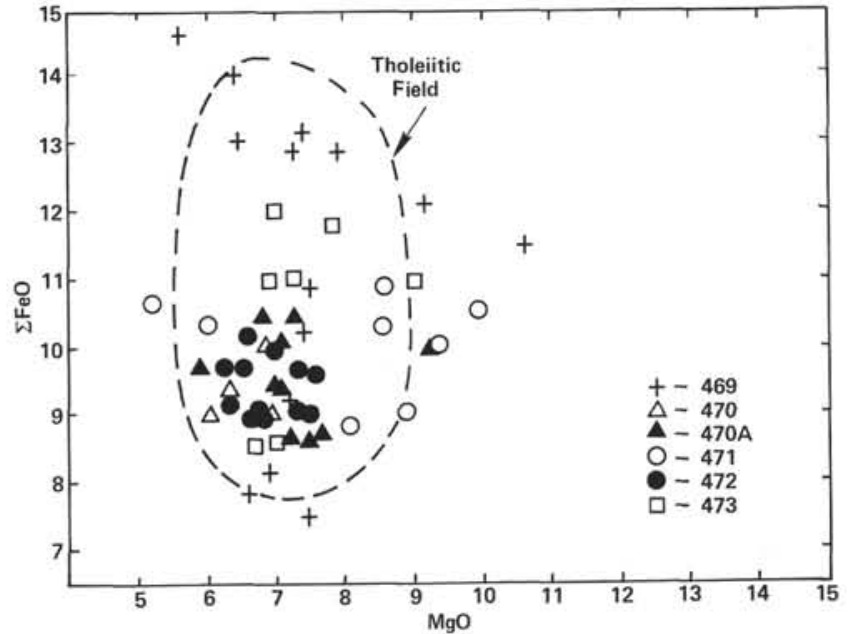

Figure 2. Two-component variation diagram $\Sigma \mathrm{FeO} / \mathrm{MgO}$. (All values are in wt.\%.)

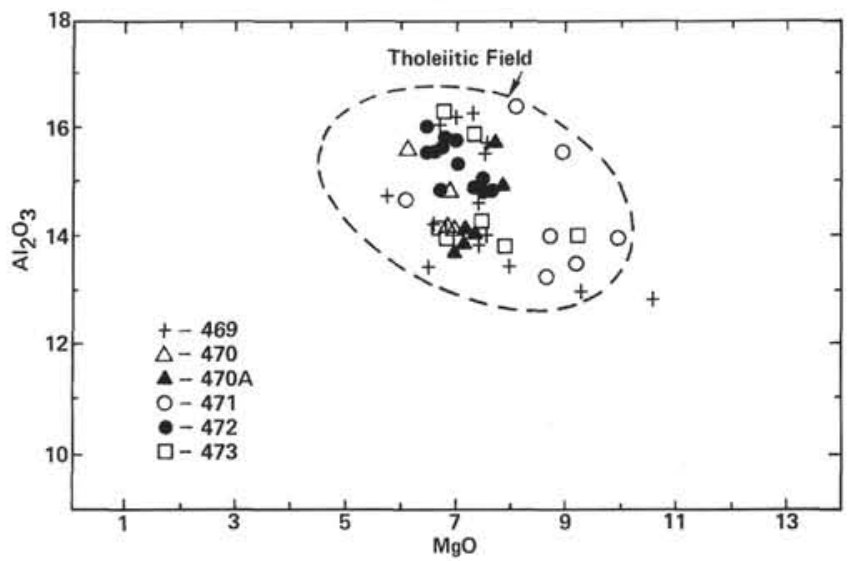

Figure 3. Two-component variation diagram $\mathrm{Al}_{2} \mathrm{O}_{3} / \mathrm{MgO}$. (All values are in wt.\%.) 


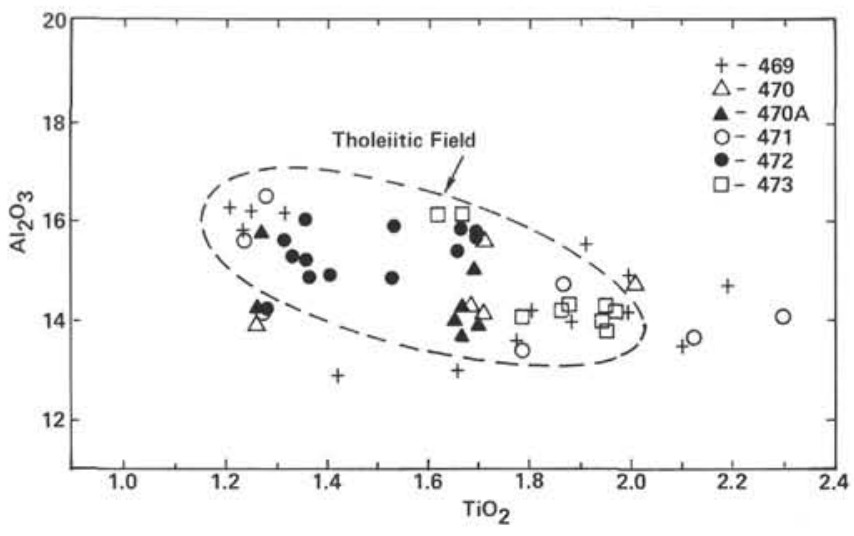

Figure 4. Two-component variation diagram $\mathrm{Al}_{2} \mathrm{O}_{3} / \mathrm{TiO}_{2}$. (All values are in wt.\%.)

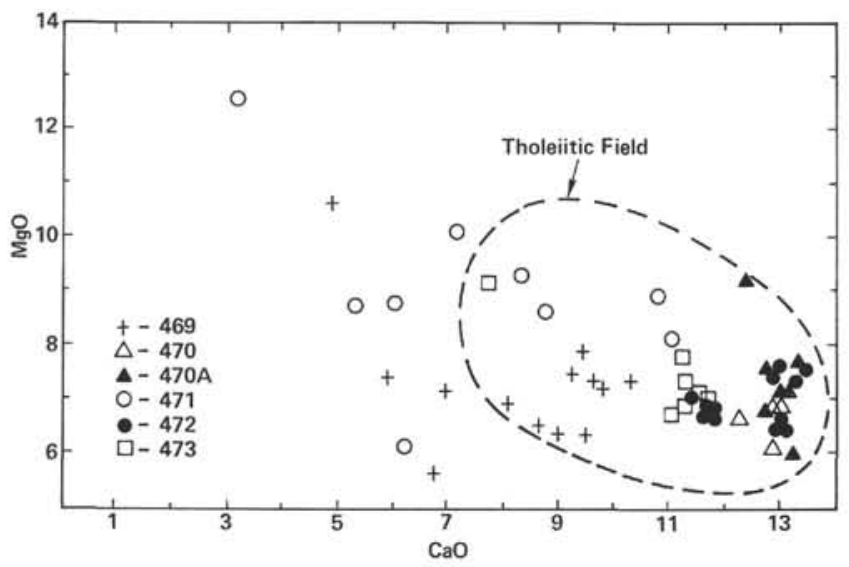

Figure 5. Two-component variation diagram $\mathrm{MgO} / \mathrm{CaO}$. (All values are in wt.\%.)

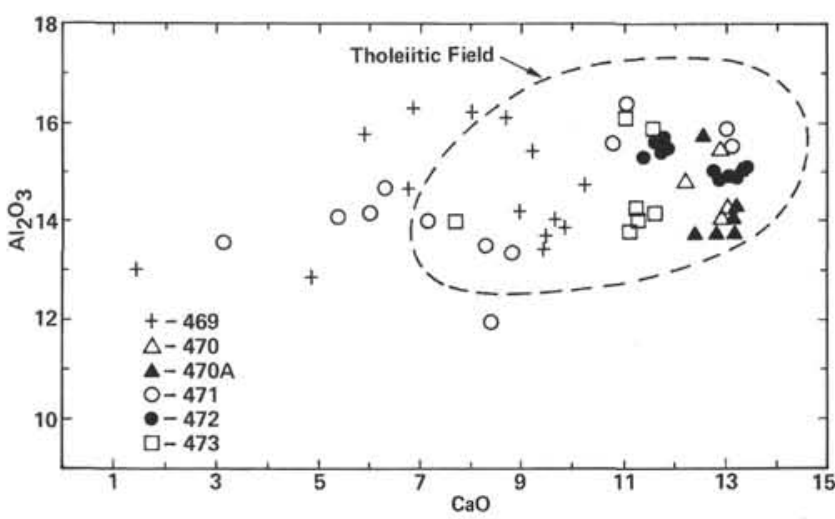

Figure 6. Two-component variation diagram $\mathrm{Al}_{2} \mathrm{O}_{3} / \mathrm{CaO}$. (All values are in wt.\%.)

chemically these rocks are similar to basalts penetrated in other holes and are assigned to a group of abyssal tholeiitic basalts. On the other hand, the rocks are most frequently holocrystalline with textures peculiar to dolerites. In the upper part of the section (247.5-248.7 $\mathrm{m})$ these rocks, like holocrystalline basalts in other holes have ophitic and, in places, intersertal texture. They are

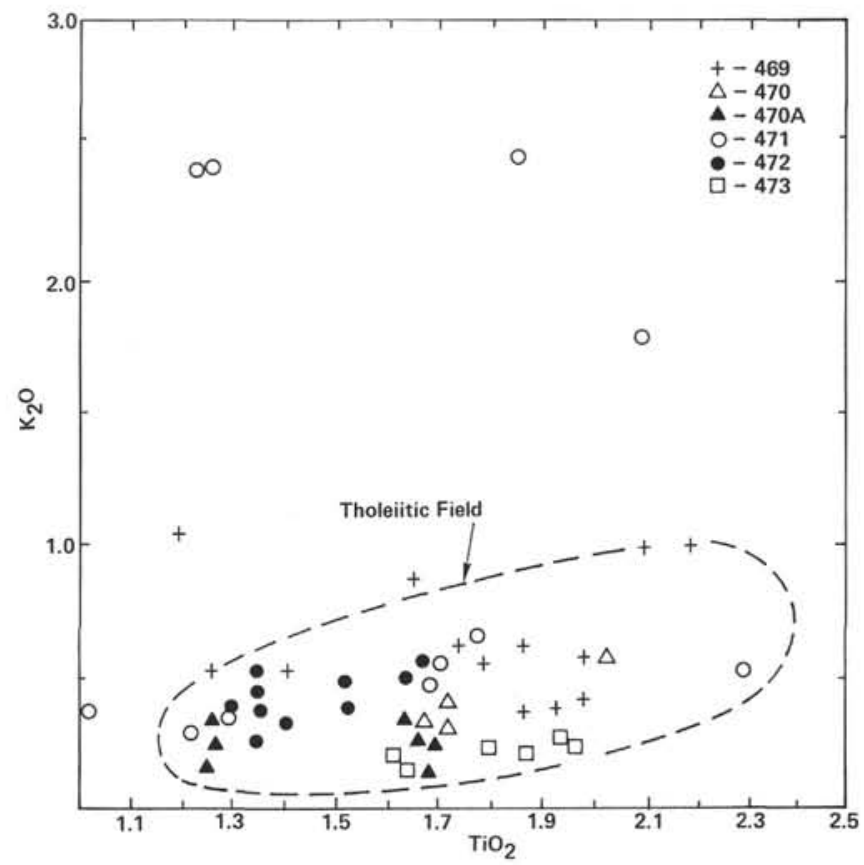

Figure 7. Two-component variation diagram $\mathrm{K}_{2} \mathrm{O} / \mathrm{TiO}_{2}$. (All values are in wt.\%.)

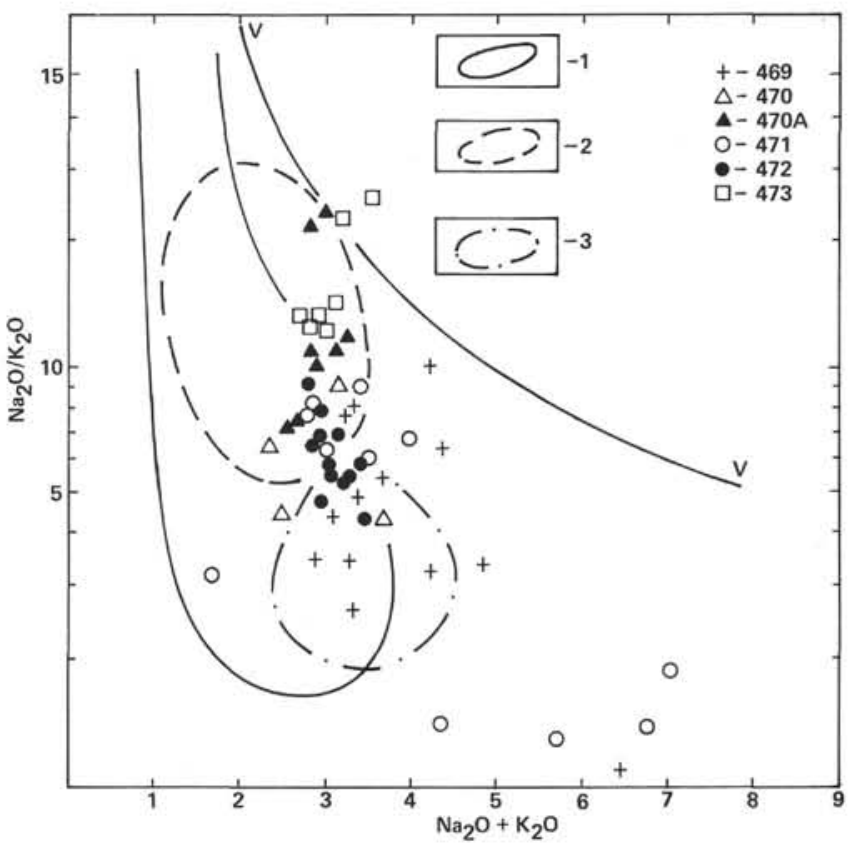

Figure 8. Miyashiro (1975) diagram. $(1=$ field of Icelandic tholeiites; $2=$ field of abyssal oceanic tholeiites; $3=$ field of alkalineolivine basalts of the Atlantic Ocean islands; and $v-v=$ the line separating the field of secondarily altered rocks. All values are in wt.\%.)

composed of large plagioclase laths and rare microphenocrysts of plagioclase, pyroxene, and olivine. The groundmass of a rock is represented by microcrystals of plagioclase, pyroxene, olivine, and, less frequently, glass. Clay minerals develop after interstitial glass, filling pores and cavities in rocks. Frequently clay minerals 


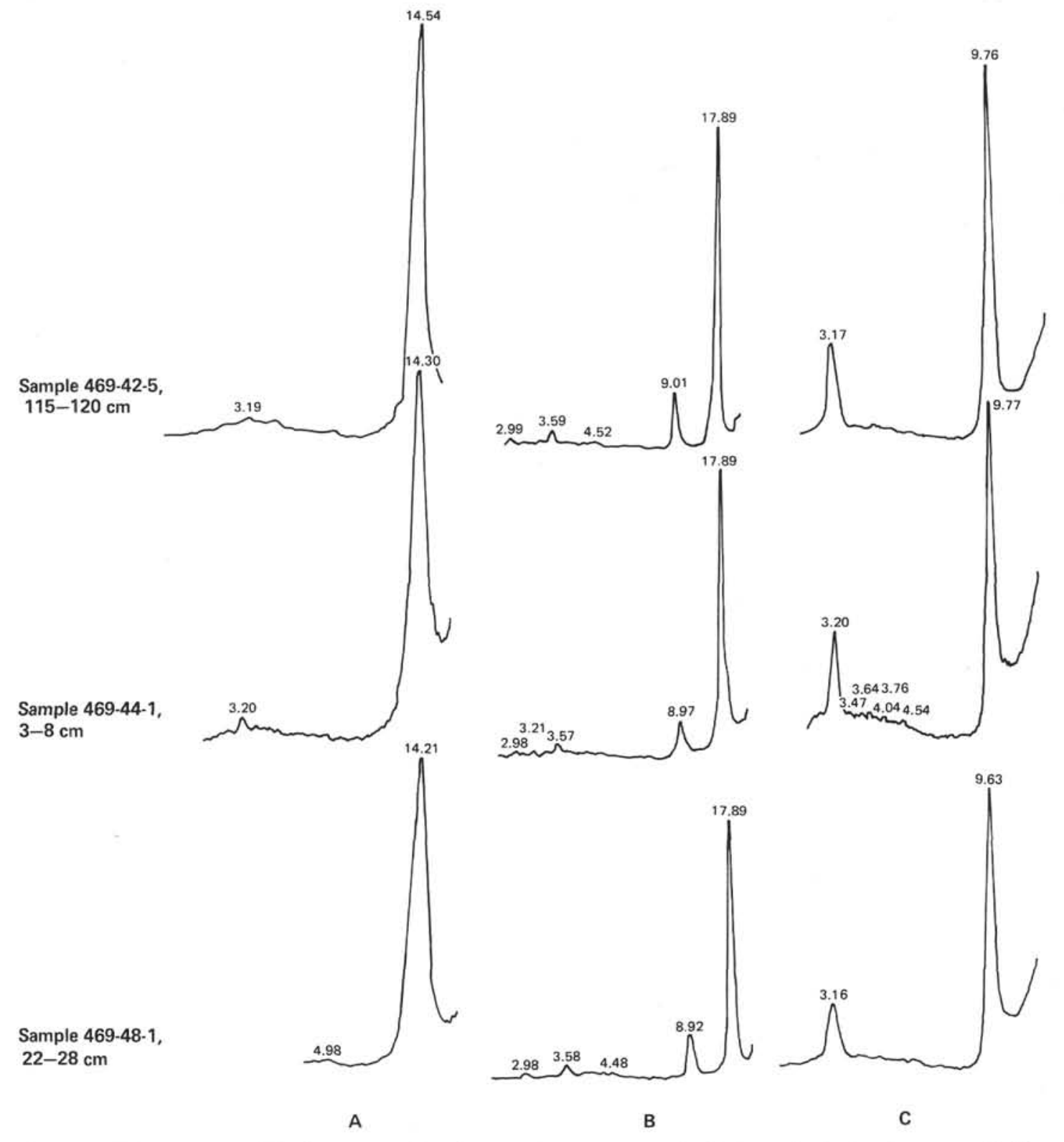

Figure 9. Diffractograms of the clay fraction from basalts of Hole 469. A. Air-dried sample. B. Sample saturated with glycerine. C. Sample heated at $550^{\circ}$.

Table 2. Balance of chemical elements in secondary alteration of dolerites at Site 469 relative to Sample 469-42-2, 117-120 cm.

\begin{tabular}{lcrrrrrrrr}
\hline \multirow{2}{*}{$\begin{array}{c}\text { Sample } \\
\text { (interval in cm) }\end{array}$} & $\mathrm{K}$ & $\mathrm{Na}$ & $\mathrm{Ca}$ & $\mathrm{Mg}$ & $\mathrm{Fe}$ & $\mathrm{Al}$ & $\mathrm{Ti}$ & $\mathrm{Si}$ & $\mathrm{OH}$ \\
\hline & & & & \\
$469-40-1,30-32$ & +32 & -5 & -27 & +13 & -4 & -2 & 0 & -12 & +33 \\
$469-41-1,7-10$ & +2 & 0 & -6 & +2 & 0 & -100 & 0 & -12 & +31 \\
$469-42-5,115-120$ & +8 & 0 & -18 & +93 & +10 & +1 & -1 & -20 & +43 \\
\hline
\end{tabular}

replace olivine and in some cases corrode pyroxene grains. Clay minerals also compose some parts of basalts apparently previously composed of glass and olivine (Sample 473-29-1, 90-95 cm). Below 252.0 meters, the rocks are represented by dolerites with ophitic and intergranular textures. The composition of dolerites is similar to that of overlying basaltic rocks, however, they contain somewhat more pyroxene and
Table 3. Balance of chemical elements in secondary alteration of basalts at Site 469 , relative to Sample $469-44-1,3-8 \mathrm{~cm}$.

\begin{tabular}{lrrlllllll}
\hline \multirow{2}{*}{$\begin{array}{c}\text { Sample } \\
\text { (interval in cm) }\end{array}$} & \multicolumn{10}{c}{ K } & $\mathrm{Na}$ & $\mathrm{Ca}$ & $\mathrm{Mg}$ & $\mathrm{Fe}$ & $\mathrm{Al}$ & $\mathrm{Ti}$ & $\mathrm{Si}$ & $\mathrm{OH}$ \\
\cline { 2 - 9 } & & & & & \\
$469-44-2,110-113$ & +2 & -9 & -5 & +1 & +2 & -2 & -1 & -4 & +19 \\
$469-45-1,3-9$ & +2 & -2 & -15 & -7 & -2 & -4 & 0 & -11 & +24 \\
$469-45-2,11-17$ & 0 & -7 & -3 & -5 & -16 & 0 & -1 & -11 & +11 \\
$469-46-1,134-138$ & +7 & +2 & -39 & -30 & +4 & -3 & +2 & -32 & +54 \\
$469-47-3,86-92$ & +1 & -6 & -9 & -7 & +6 & -13 & 0 & -15 & +11 \\
\hline
\end{tabular}

much less olivine. The dolerites are strongly altered by secondary processes. The main secondary minerals are clay minerals, less important ones are calcite and quartz. Clay minerals are distributed unevenly. In some places they compose the entire groundmass, developing after all minerals except plagioclase and filling pore 

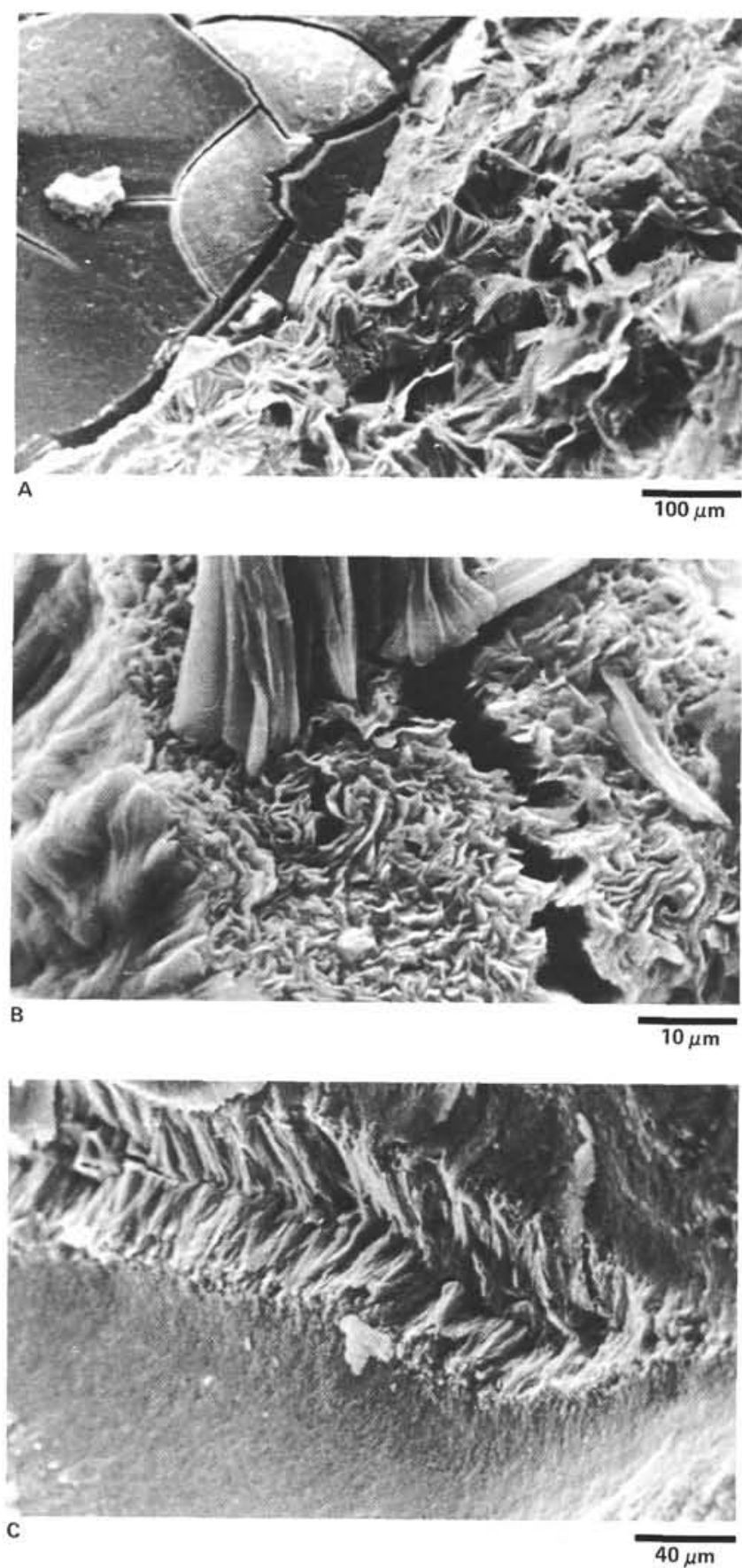

Figure 10. Scanning electron microscope pictures of aggregates of smectites developed after sideromelane glass (Sample 469-48-1, $22-28 \mathrm{~cm})$. A. Frontal alteration of glass. B. Fragment of smectite aggregate. C. Development of smectite after fissures in glass.

spaces and fissures in rocks. Clay minerals may have wholly replaced olivine (Sample 473-32-2, 113-140 cm). In less altered varieties of dolerites (Sample 473-32-3, 51-57), clay minerals develop during alteration of olivine, corrode grains of pyroxene, develop after interstitial glass, and fill fissures and pores in rocks. Clay and ore minerals are associated with olivine grains.

In X-ray diffractograms clay minerals in an air-dried state have the first basal reflections with $d=14.2$ to
14.3 $\AA$. After saturation with glycerine, the diffractograms show reflections with $d=17.9$ to $18.0 \AA$, and after heating at $550^{\circ} \mathrm{C}$, show reflections with $d=$ $9.98 \AA$ and with $d=9.59 \AA$ (Fig. 14). The clay minerals having a reflection with $d=9.98 \AA$ after heating are a mixed-layer smectite-mica with $15 \%$ to $20 \%$ micaceous layers. The clay minerals with the reflection $9.59 \AA$ after heating belong to magnesium smectites, possibly with a small admixture of Fe-smectite and the nontronitic type (Fig. 14).

The chemical composition of basalts is similar to that of dolerites (Table 1). Chemical formulas after Barth (1948) follow:

$$
\begin{aligned}
& \text { Sample 473-29-1, 90-95 cm, } \\
& \mathrm{K}_{1} \mathrm{Na}_{60} \mathrm{Ca}_{111} \mathrm{Mg}_{94} \mathrm{Fe}_{68} \mathrm{Al}_{180} \mathrm{Ti}_{12} \mathrm{Si}_{474} \mathrm{P}_{1}\left(\mathrm{O}_{1563} \mathrm{OH}_{37}\right) \\
& \text { Sample 473-30-2, 126-134 cm, } \\
& \mathrm{K}_{1} \mathrm{Na}_{54} \mathrm{Ca}_{116} \mathrm{Mg}_{101} \mathrm{Fe}_{67} \mathrm{Al}_{172} \mathrm{Ti}_{11} \mathrm{Si}_{472} \mathrm{P}_{1}\left(\mathrm{O}_{1563} \mathrm{OH}_{37}\right) \\
& \text { Sample 473-32-2, 133-140 cm, } \\
& \mathrm{K}_{2} \mathrm{Na}_{54} \mathrm{Ca}_{76} \mathrm{Mg}_{125} \mathrm{Fe}_{84} \mathrm{Al}_{151} \mathrm{Ti}_{13} \mathrm{Si}_{442} \mathrm{P}_{1}\left(\mathrm{O}_{1471} \mathrm{OH}_{124}\right) \\
& \text { Sample 473-32-3, 51-57 cm, } \\
& \mathrm{K}_{2} \mathrm{Na}_{48} \mathrm{Ca}_{115} \mathrm{Mg}_{105} \mathrm{Fe}_{92} \mathrm{Al}_{160} \mathrm{Ti}_{14} \mathrm{Si}_{473} \mathrm{P}_{1}\left(\mathrm{O}_{1568} \mathrm{OH}_{32}\right) \\
& \text { Sample 473-33-2, 139-145 cm, } \\
& \mathrm{K}_{2} \mathrm{Na}_{48} \mathrm{Ca}_{118} \mathrm{Mg}_{97} \mathrm{Fe}_{91} \mathrm{Al}_{158} \mathrm{Ti}_{14} \mathrm{Si}_{471} \mathrm{P}_{1}\left(\mathrm{O}_{1556} \mathrm{OH}_{44}\right) \\
& \text { Sample 473-34-1, 0-6 cm, } \\
& \mathrm{K}_{2} \mathrm{Na}_{48} \mathrm{Ca}_{114} \mathrm{Mg}_{111} \mathrm{Fe}_{96} \mathrm{Al}_{154} \mathrm{Ti}_{14} \mathrm{Si}_{470} \mathrm{P}_{1}\left(\mathrm{O}_{1575} \mathrm{OH}_{25}\right)
\end{aligned}
$$

The comparison of these formulas allows us to conclude that in the processes of secondary alteration of Hole 473 basalts no changes occurred in overall chemical composition of the rocks. The intensity of development of secondary products is evidenced by the content of the $\mathrm{OH}$ group in the above formulas. The most altered rock is characterized by the $\mathrm{OH}$ group content equal to 124 , whereas for slightly altered rocks the value varies from 25 to 37 . On the whole, strongly altered basalts in Hole 473 contain very little potassium. Consequently, this element is not indicative here of the degree of secondary alteration of the basalts and dolerites. As for magnesium, its content in altered basalts of Hole 473 is approximately similar to that in rocks from Holes 469 , $470,470 \mathrm{~A}, 472$. The average content of $\mathrm{MgO}$ in all these rocks is $0.20 \mathrm{~g} / \mathrm{cm}^{3}$.

The general peculiarity of the altered basalts in all Leg 63 holes (except Hole 471) is the development of clay minerals of a smectitic composition. These minerals are either disordered mixed-layer smectite-mica complexes with a small amount of micaceous layers (in which smectitic layers are of an iron-magnesium composition) or an iron-rich nontronitelike mineral. A different composition of secondary products of basalt alteration was observed in Hole 471 rocks. Along with formation of smectites, chloritization also occurred.

\section{Hole 471}

Dolerites were found in Hole 471 from 741 to 820 meters sub-bottom depth. In the upper part of the section, at a depth of 741 to $\mathbf{7 4 2}$ meters, dolerites are strongly altered. The texture of rocks is ophitic, intersertal, sometimes microgabbroic. Dolerites consist of large laths of plagioclase and pyroxene; the groundmass is composed of secondary minerals. As the grains of a rock become coarser, idiomorphism of pyroxene increases. Secondary products are composed of calcite 
A

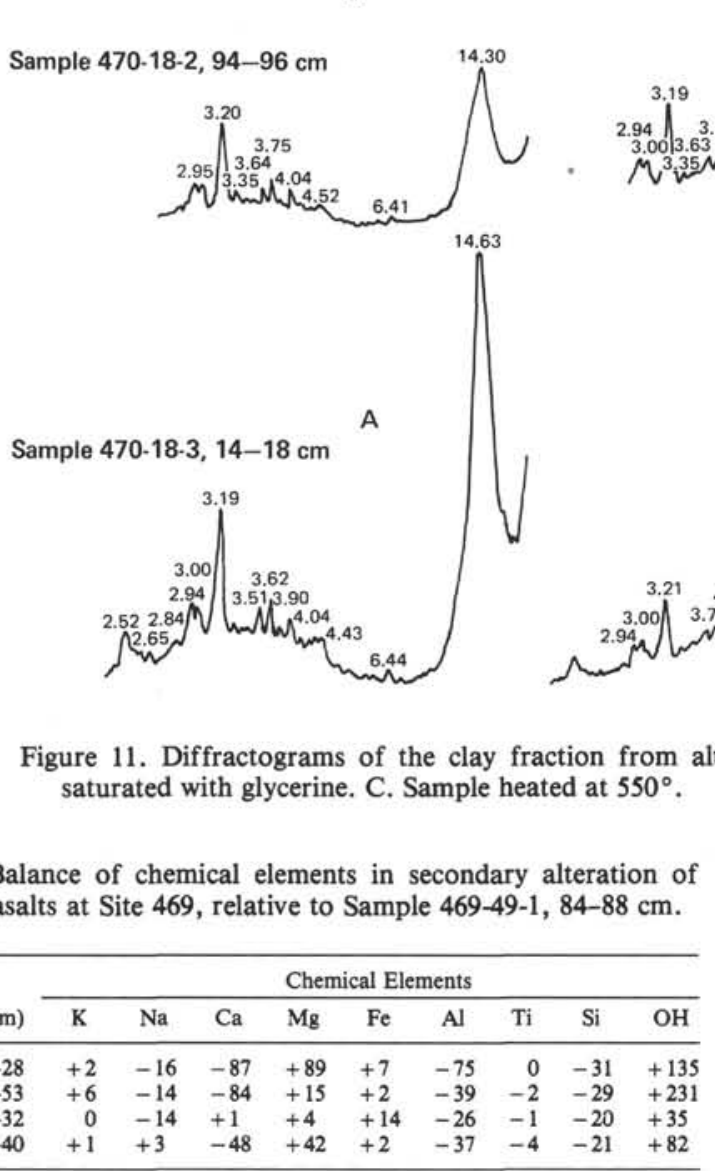

and clay minerals. Calcite forms pseudomorphs after dark-colored minerals, less frequently after plagioclases, and fills pore spaces and fissures in plagioclases. Clay minerals develop after dark-colored minerals and in interstices (Sample 471-79-1, 130-137 cm).

According to X-ray diffraction data, the clay mineral is represented by $\mathrm{Fe}-\mathrm{Mg}$ chlorite showing in a diffractogram a series of basal reflections with $d=14.3 \AA$. After heating at $550^{\circ} \mathrm{C}$, the height of the chlorite peak decreases to $14.0 \AA$, and intensity of lower-order basal reflections sharply decreases (Fig. 15). Such chlorite is of the "imperfect" structure resulting from abundant one-story brucitic layers. After saturation with glycerine, a weak reflection with $d=17.7 \AA$ peculiar to smectite appears in a diffractogram. Thus Sample 471-79-1, 130-137 cm contains mostly chlorite and a small mixture of smectite (Fig. 15).

Downward in the section, dolerites are composed of large, unoriented laths of plagioclase and microphenocrysts of plagioclase, pyroxene, and olivine. The groundmass consists of pyroxene, olivine, and interstitial glass. The rocks are of an intersertal structure. Dolerites are sometimes strongly altered; all dark-colored minerals and glass are replaced by clay minerals and partly by carbonates. Some rocks appear fresh. Originally, clay minerals in dolerites developed after interstitial glass, the patches of the latter being rather large. Subsequently, clay minerals replaced dark-colored components of a rock and, finally, these minerals crystallized in pore space where they formed pseudooolitic aggregates.

$\mathrm{X}$-ray diffraction studies of the clay fraction showed that two clay minerals were present: smectite and mixedlayer smectite-chlorite (Sample 471-80-1, 78-84 cm). After saturation of the sample with glycerine, a diffractogram shows reflections with $d=17.87,9.01,4.57$, and $3.59 \AA$, with intensities peculiar to $\mathrm{Mg}$-smectite of the saponitic type. In a diffractogram of an air-dried sample, there is a series of intense basal reflections with $d=14.5,7.23,4.83,3.61$, and $2.96 \AA$, which can be attributed to a mixed-layer smectite-chlorite. After heating at $550^{\circ} \mathrm{C}$, diffractograms show reflections with $d=13.3$ and $9.8 \AA$; the first reflection belongs to chlorite, the second one to dehydrated smectite. A peculiar structural characteristic of mixed-layer smectite-chlorite is chloritic layers that look "imperfect" because of the abundant brucitic layers (Fig. 15).

In the interval from 752 to 781 meters sub-bottom depth (Samples 471-80-2, 98-102 cm, 471-81-3, 59-65 $\mathrm{cm}, 471-83-2,61-67 \mathrm{~cm}$ ), dolerites are strongly altered by secondary processes. Only relics of large laths and rare microphenocrysts of plagioclase (and less frequently pyroxene) are recognized in these rocks. Almost all dark-colored minerals and interstitial glass are replaced by aggregates of clay minerals. Clay minerals form patches, fill veins and pores, and are pseudomorphs after primary minerals. Areas composed of fanlike aggregates with well-expressed elongated platy crystals (Fig. 16, A, B, C) are distinguished within a finely dispersed mass. A chalcedonylike mineral forming pyramidal crystals (Fig. 17, A, B) is observed in some pores. This mineral has optical properties of chalcedony, but according to microsounding data it contains up to $12 \% \quad \mathrm{Al}_{2} \mathrm{O}_{3}$. Sometimes $\mathrm{K}$-feldspar has 


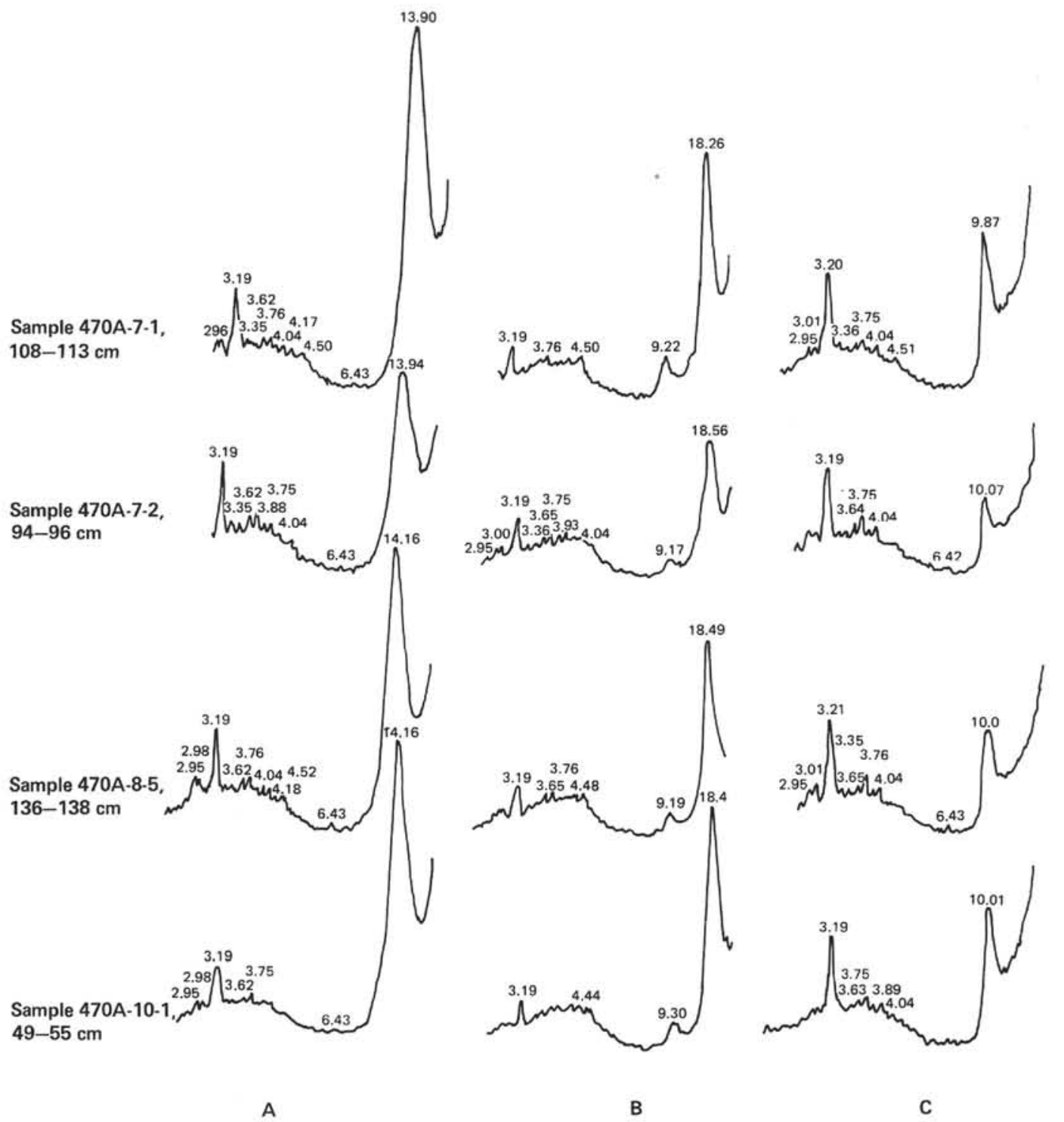

Figure 12. Diffractograms of the clay fraction from altered basalts in Hole 470A. A. Air-dried sample. B. Sample saturated with glycerine. C. Sample heated at $550^{\circ}$.

replaced crystals of plagioclase and can be recognized in the groundmass in the form of anhedral patches. On the basis of XRD data, K-feldspar separated from Sample 471-80-2, 98-102 cm is of a sanidine character (Fig. 18). It is low sanidine (Barth, 1969) that is of almost pure potassium composition $\left(\Delta_{\mathrm{p}}=0, \Delta_{\mathrm{z}}=0.21, \mathrm{Al}_{\mathrm{T}_{1}}=30\right.$, $\mathrm{Al}_{\mathrm{T}_{2}}=20$ ).

In the X-ray diffractogram of the $0.001 \mathrm{~mm}$ fraction of Sample 471-80-2, 98-102 cm, a series of basal reflections is distinguished in addition to the principal basal reflection $d=29.85 \AA$. Similarly, the same sample saturated with glycerine has a series of basal reflections along with the principal one $(d=32.2 \AA)$. After heating at $550^{\circ} \mathrm{C}$, the structure of the mineral contracts and the first basal reflection has $d=22.7 \AA$ (Fig. 15). Such a diffraction pattern is peculiar to a mixed-layer smectite-chlorite containing approximately equal amounts of smectite and chlorite layers in nearly ordered alternation. This is a corrensitelike mineral. The mineral contains $\mathrm{SiO}_{2}-35.82 \% ; \mathrm{Al}_{2} \mathrm{O}_{3}-12.51 \% ; \quad \mathrm{Fe}_{2} \mathrm{O}_{3} \%$, $\mathrm{Fe}_{2} \mathrm{O}_{3}-6.42 \%, \mathrm{FeO}-9.03 \%, \mathrm{MnO}-0.23 \%, \mathrm{CaO}-$ $1.18 \%, \mathrm{MgO}-19.37 \%, \mathrm{Na}_{2} \mathrm{O}-0.42 \%, \mathrm{~K}_{2} \mathrm{O}-0.44 \%$, LOI- $14.95 \%$.

In Sample 471-81-3, 59-65 cm, besides a corrensitelike mineral, there is a small amount of "imperfect" chlorite. In the diffractogram of a sample heated at $550^{\circ} \mathrm{C}$, there are no reflections of the lower orders from $14 \AA$ (Fig. 15).

In Sample 471-83-2, 61-67 cm, along with a corrensitelike mineral, there is a small amount of smectite. This mineral is distinguished by a reflection with $d=$ $17.82 \AA$ in the diffractogram of a specimen saturated with glycerine. The same sample contains a certain amount of chlorite that has a reflection with $d=$ $14.3 \AA$. in the diffractogram of a specimen heated at $550^{\circ} \mathrm{C}$. A corrensitelike mineral and chlorite fill spaces between crystals of plagioclases and relics of other minerals. In a scanning-electron microscope picture, the 


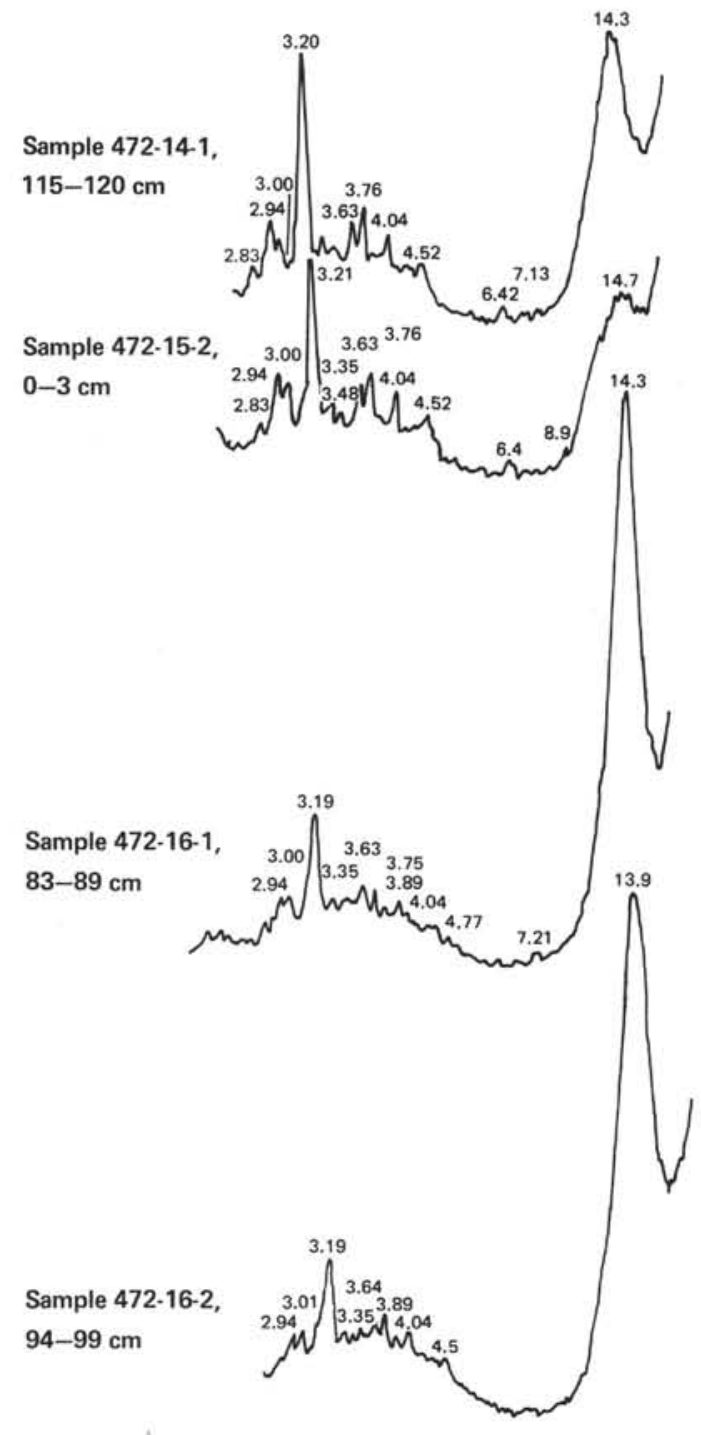

A
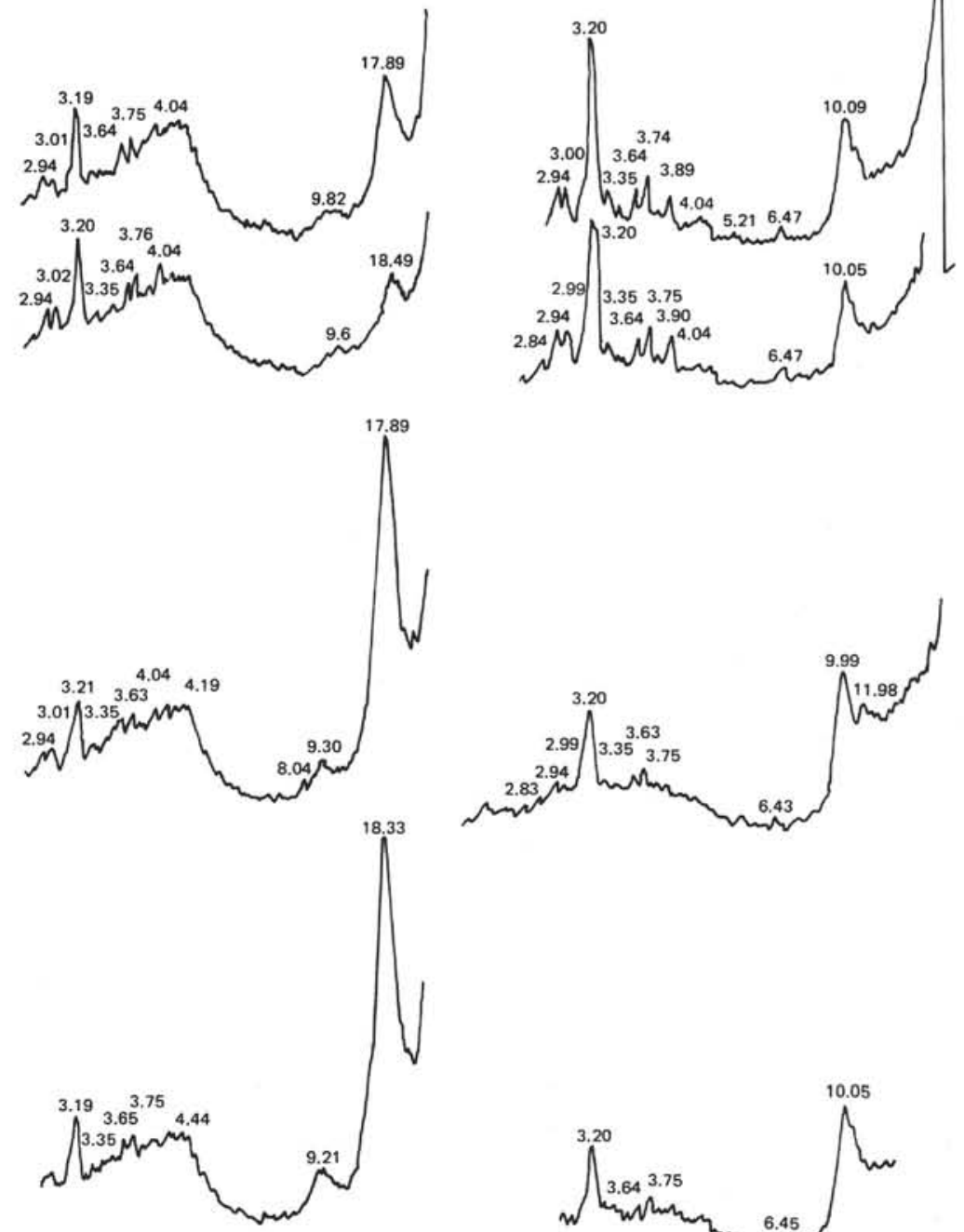

B

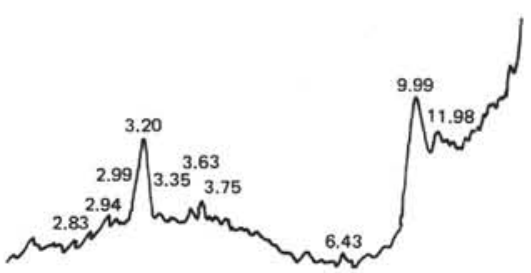

Figure 13. Diffractograms of the clay fraction from altered basalts in Hole 472. A. Air-dried sample. B. Sample saturated with glycerine. C. Sample heated at $550^{\circ}$.

Table 5. Balance of chemical elements in secondary alteration of basalts in Hole 472 relative to Sample $472-15-1,20-24 \mathrm{~cm}$.

\begin{tabular}{lrrrrrrrrr}
\hline \multirow{1}{*}{$\begin{array}{c}\text { Sample } \\
\text { (interval in cm) }\end{array}$} & $\mathrm{K}$ & $\mathrm{Na}$ & $\mathrm{Ca}$ & $\mathrm{Mg}$ & $\mathrm{Fe}$ & $\mathrm{Al}$ & $\mathrm{Ti}$ & $\mathrm{Si}$ & $\mathrm{OH}$ \\
\cline { 2 - 9 } & & & & & & \\
$472-14-1,115-120$ & +1 & -4 & +3 & -9 & +5 & +2 & -1 & -9 & +32 \\
$472-14-2,76-82$ & 0 & -4 & +7 & +1 & -4 & +4 & -1 & -11 & +13 \\
$472-15-1,69-77$ & -1 & -3 & +1 & -16 & -2 & +5 & -2 & -26 & +56 \\
$472-15-2,0-3$ & +1 & -2 & +4 & -2 & -3 & +2 & -1 & -7 & +13 \\
$472-15-2,9-14$ & -2 & -4 & +1 & +3 & -1 & +3 & -1 & -2 & +1 \\
$472-15-2,69-75$ & +1 & 0 & -12 & -12 & 0 & +3 & +1 & -13 & +31 \\
$472-15-2,91-98$ & +1 & +4 & -11 & -8 & -3 & +12 & 0 & -8 & +13 \\
$472-16-1,12-15$ & -2 & -5 & 0 & -16 & -6 & +20 & -1 & -24 & +37 \\
$472-16-1,83-89$ & +1 & -2 & -12 & -8 & -4 & +9 & +1 & -7 & +8 \\
$472-16-1,145-150$ & +2 & +1 & -10 & -9 & -6 & +10 & +1 & -3 & +32 \\
$472-16-2,94-99$ & +1 & 0 & -15 & -7 & +1 & +5 & 0 & -12 & +31 \\
\hline
\end{tabular}

corrensitelike mineral has slightly curved, platy crystals; chlorite has undeformed, strictly parallel, platy crystals (Fig. 19).

Beginning at the sub-bottom depth of 787 meters in a strongly altered dolerite, clay minerals compose cement of the basal type. Plagioclase and, to a lesser extent, pyroxene and olivine remain relic minerals in these rocks. These minerals are strongly corroded and replaced by clay. The character and texture of the clay cement are diverse; coronated, separately oriented packets, microveins, and oriented aggregates filling pores and fissures occur (Fig. 20, A-C). Clay minerals in altered dolerites at these depths are represented by $\mathrm{Mg}$ smectite of the saponite type admixed with chlorite. 


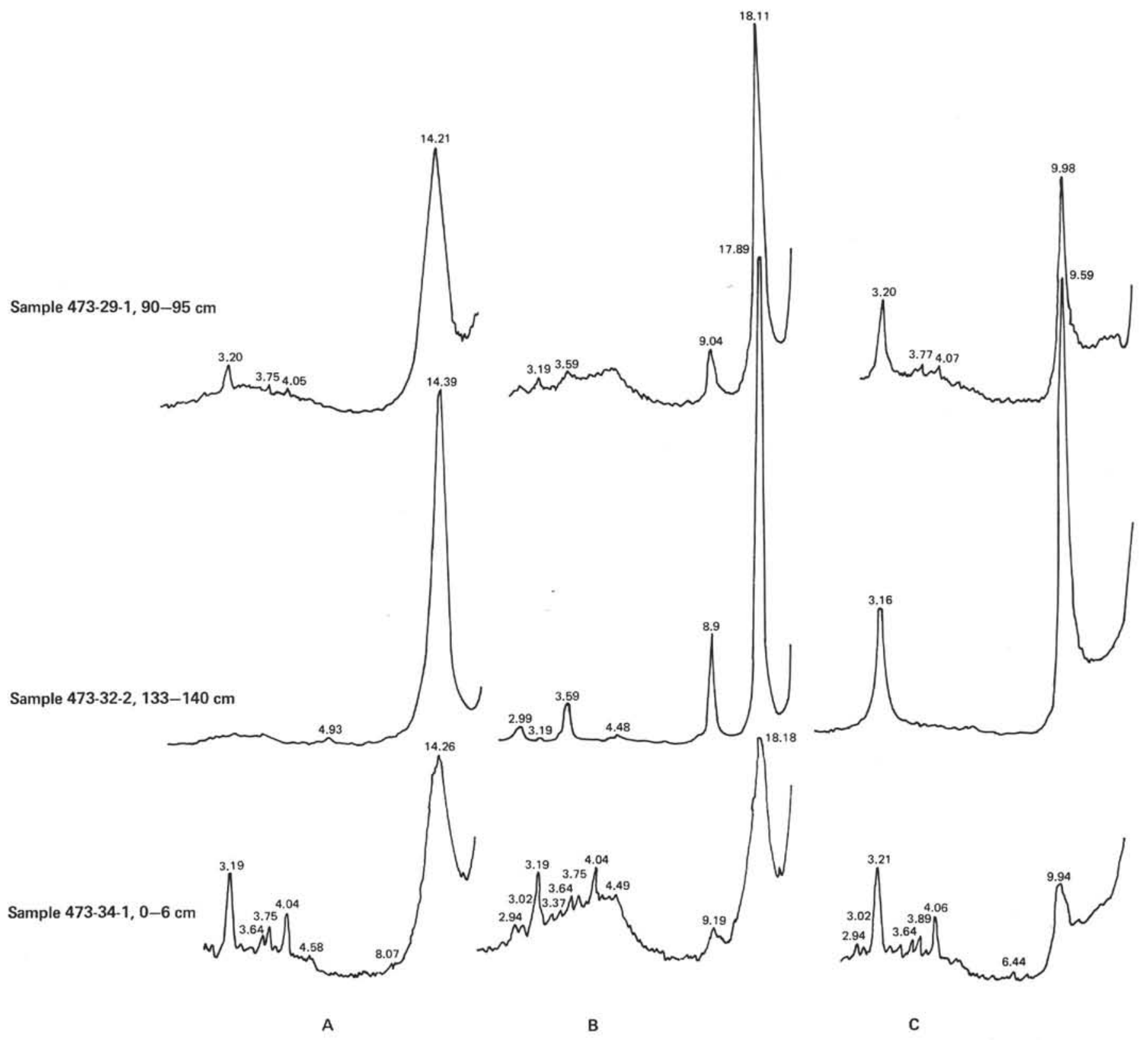

Figure 14. Diffractograms of the clay fraction from altered basalts in Hole 473. A. Air-dried sample. B. Sample saturated with glycerine. C. Sample heated at $550^{\circ}$.

A series of basal reflections from 14.78 and $14.63 \AA$ is presented in diffractograms of air-dried samples $471-86-1,63-69 \mathrm{~cm}$ and $471-88-2,0-6 \mathrm{~cm}$. The glycerine complex of minerals expands to $d=17.89$ to $18.0 \AA$. After heating at $550^{\circ} \mathrm{C}$, the minerals yield reflections of the first order with $d=9.64$ to $9.67 \AA$. The mineral studied is a smectite with a small amount of interlayers of the micaceous type (mixed-layer clay). Chlorite is singled out by reflectons with $d=13.87$ to $14.21 \AA$ displayed in diffractograms of samples heated at $550^{\circ} \mathrm{C}$ (Fig. 15). Thus in altered dolerites in the upper part of Hole 471 we can observe the development of chlorite and, in much smaller amounts, smectite. Downward in the section, the amount of smectite among secondary products of alteration increases. The middle part of altered dolerites contains abundant amounts of a corrensitelike mineral that is similar to the ordered mixedlayer chlorite-smectite. Disordered mixed-layer chlorite-smectite with predominance of smectitic layers is less abundant. Finally, smectite admixed with a small amount of chlorite predominates in the lower part of the altered dolerites.

The chemical composition of Hole $\mathbf{4 7 1}$ dolerites is given in Table 6. Formulas of the chemical composition of dolerites recalculated after Barth (1948) follow.

Sample 471-80-1, 78-84 cm, $\mathrm{K}_{6} \mathrm{Na}_{53} \mathrm{Ca}_{71} \mathrm{Mg}_{138} \mathrm{Fe}_{84} \mathrm{Al}_{152} \mathrm{Ti}_{16} \mathrm{Si}_{425} \mathrm{P}_{1}\left(\mathrm{O}_{1453} \mathrm{OH}_{147}\right)$ Sample 471-80-2, 98-102 cm, $\mathrm{K}_{19} \mathrm{Na}_{40} \mathrm{Ca}_{28} \mathrm{Mg}_{158} \mathrm{Fe}_{82} \mathrm{Al}_{134} \mathrm{Ti}_{13} \mathrm{Si}_{374} \mathrm{P}_{1}\left(\mathrm{O}_{1293} \mathrm{OH}_{307}\right)$ 
Sample 471-81-3, 59-65 cm, $\mathrm{K}_{27} \mathrm{Na}_{79} \mathrm{Ca}_{60} \mathrm{Mg}_{80} \mathrm{Fe}_{67} \mathrm{Al}_{153} \mathrm{Ti}_{13} \mathrm{Si}_{453} \mathrm{P}_{1}\left(\mathrm{O}_{1435} \mathrm{OH}_{165}\right)$ Sample 471-82-1, 127-132 cm, $\mathrm{K}_{26} \mathrm{Na}_{58} \mathrm{Ca}_{56} \mathrm{Mg}_{114} \mathrm{Fe}_{77} \mathrm{Al}_{145} \mathrm{Ti}_{8} \mathrm{Si}_{430} \mathrm{P}_{1}\left(\mathrm{O}_{1397} \mathrm{OH}_{203}\right)$ Sample 471-82-2, $15-18 \mathrm{~cm}$, $\mathrm{K}_{26} \mathrm{Na}_{54} \mathrm{Ca}_{50} \mathrm{Mg}_{113} \mathrm{Fe}_{77} \mathrm{Al}_{144} \mathrm{Ti}_{8} \mathrm{Si}_{430} \mathrm{P}_{1}\left(\mathrm{O}_{1386} \mathrm{OH}_{214}\right)$ Sample 471-84-1, 9-16 cm, $\mathrm{K}_{6} \mathrm{Na}_{62} \mathrm{Ca}_{83} \mathrm{Mg}_{129} \mathrm{Fe}_{77} \mathrm{Al}_{149} \mathrm{Ti}_{12} \mathrm{Si}_{444} \mathrm{P}_{1}\left(\mathrm{O}_{1476} \mathrm{OH}_{124}\right)$ Sample 471-84-1-(107-114) $\mathrm{K}_{3} \mathrm{Na}_{51} \mathrm{Ca}_{85} \mathrm{Mg}_{116} \mathrm{Fe}_{82} \mathrm{Al}_{141} \mathrm{Ti}_{12} \mathrm{Si}_{426} \mathrm{P}_{2}\left(\mathrm{O}_{1445} \mathrm{OH}_{155}\right)$ Sample 471-86-1-(63-69) $\mathrm{K}_{3} \mathrm{Na}_{46} \mathrm{Ca}_{108} \mathrm{Mg}_{110} \mathrm{Fe}_{69} \mathrm{Al}_{176} \mathrm{Ti}_{9} \mathrm{Si}_{435} \mathrm{P}_{1}\left(\mathrm{O}_{1479} \mathrm{OH}_{121}\right)$ Sample 471-87-2-(19-26)

The secondary products of alteration in these dolerites have different mineral compositions, ranging from chlorite and corrensite to smectite. The dolerites themselves are petrochemically similar to those of Hole 469, in which the least altered is Sample 469-42-1, $117-120 \mathrm{~cm}$. Therefore, we balanced the major rockforming chemical elements in a section of altered dolerites from Hole 471 relative to Sample 469-42-1, $117-120 \mathrm{~cm}$ (Table 6).

In all samples of altered dolerites from Hole 471 a relative decrease of $\mathrm{Al}$ and $\mathrm{Si}$ contents, an increase of $\mathrm{Mg}$ and $\mathrm{Fe}$ contents, and strong hydration of the rock are recorded. Dolerites from the upper part of the hole contain corrensite, and $\mathrm{K}$-feldspars are characterized by a relative increase of $\mathrm{K}$ content and decrease of $\mathrm{Ca}$ content. In rocks from the lower part of the section, the $\mathrm{K}$ content remains practically constant. Potassium in these rocks appears to be concentrated in $\mathrm{K}$-feldspar and corrensite.

In the corrensitelike mineral, consisting of smectitic and chloritic interlayers, the $\mathrm{K}_{2} \mathrm{O}$ content $(0.44 \% \mathrm{~K})$ could either have been adsorbed or combined in smectitic interlayers. This variation is suggested by the principal peak with $d=32.2 \AA$ in diffractograms of the sample containing the corrensitelike mineral saturated with glycerine (Sample 471-80-2, 98-102 cm, Fig. 15). A tendency toward layer-by-layer enrichment of smectite with $\mathrm{K}$ is especially well delineated by microsounding of large fanlike aggregates of this mineral (Sample 471$88-2,0-6 \mathrm{~cm}$, Fig. 21). The figures clearly show striation (banding) and even distribution of $\mathrm{Mg}$. Smectitic components of altered dolerites concentrate $\mathrm{K}$. According to microsounding data, the $\mathrm{K}_{2} \mathrm{O}$ content in smectites can reach $23 \%$. In such smectites, $\mathrm{K}$ forms micaceous layers and averages about $15 \%$. Almost all smectites in altered basalts of oceanic substratum contain a small amount of micaceous interlayers.

The analysis of chemical data recalculated to volume weights of altered dolerites in Hole 471 (Table 1) shows that only potassium is supplied to dolerites. In one case considerable amounts of $\mathrm{Mg}$ are supplied to a rock (Sample 471-88-2, 0-6 cm). In this rock, along with smectites, an independent chloritic phase is formed under the influence of the supplied $\mathrm{Mg}$. In the rest of the cases, redistribution of chemical elements among primary minerals and secondary products took place in the processes of secondary alteration of dolerites. Such geochemical processes could have occurred as a result of dissolution of primary minerals by weakly mineralized thermal waters and synthesis from these solutions of new minerals. Such secondary products are clay minerals represented by smectite, corrensite and chlorite, carbonate and siliceous minerals. Strong hydration of rocks accompanies the process of secondary alteration of dolerites.

\section{CONCLUSIONS}

Two structural varieties-basalts and dolerites-were recognized among volcanic rocks penetrated by drilling during DSDP Leg 63 . The first variety is unequivocally interpreted as effusive; the second one is presumably subintrusive (gently inclined or subhorizontal dikes or sills). The greater part of the volcanic rocks studied (including all basalts and dolerites of Hole 473) chemically qualify as oceanic tholeiites. Dolerites at Sites 469 and 471 are analogues of alkaline-olivine basalts. When judged by all petrochemical parameters, the rocks we studied (regardless of the degree of their alteration) belong to the tholeiitic and alkaline-olivine-basalt series. Processes of secondary mineral formation are isochemical. Localization of clay minerals (filling of vesicles and fissures) suggests alteration by mobile, weakly mineralized thermal solutions. The character of claymineral distribution in these volcanic rocks suggests that no vertical hydrothermal zonation exists in them. Maximum alterations of these rocks are associated with fractured zones.

The secondary minerals are smectites of various types and, in dolerites in Hole 471, corrensites and chlorites. At Hole 471, the chloritic component decreases downsection. Comparing the character and degree of secondary alteration of the basaltic rocks with their chemical composition reveals no pronounced differences between secondary minerals that developed in the two petrochemical groups-basalts and dolerites. Differences in chemistry of the tholeiitic and alkaline-olivine groups and conditions of their transformation do not appear significant enough to result in formation of various complexes of secondary minerals. At the same time, the composition of clay is inherited from the composition of original rocks, all of which are characterized by high $\mathrm{Mg}$ and $\mathrm{Fe}$ contents. Formation of corrensite and chlorite after dolerites at Site 471 seems to be related not to differences in the chemistry of the dolerites but to higher temperatures than in other holes and to hydrothermal activity. This is evidenced not only by intense chloritization of smectites but by rich sulphide mineralization and development of pyrite, chalcopyrite, and sphalerite in dolomitized sedimentary rocks overlying dolerites.

The secondary alteration of rocks results only in local and rather insignificant redistribution of some major elements $(\mathrm{K}, \mathrm{Fe}, \mathrm{Mg})$ and in rather strong dehydration of the basaltic rock. In this process, an insignificant inflow of $\mathrm{K}$ is accompanied variously by the outflow and inflow of $\mathrm{Mg}$ and $\mathrm{Fe}$. Sometimes $\mathrm{K}, \mathrm{Fe}$, and $\mathrm{Mg}$ all show depletions with depth. This apparent random migration of elements in the secondary transformation of the basaltic rocks in each section suggests only redistribution of the major rock-forming elements with- 


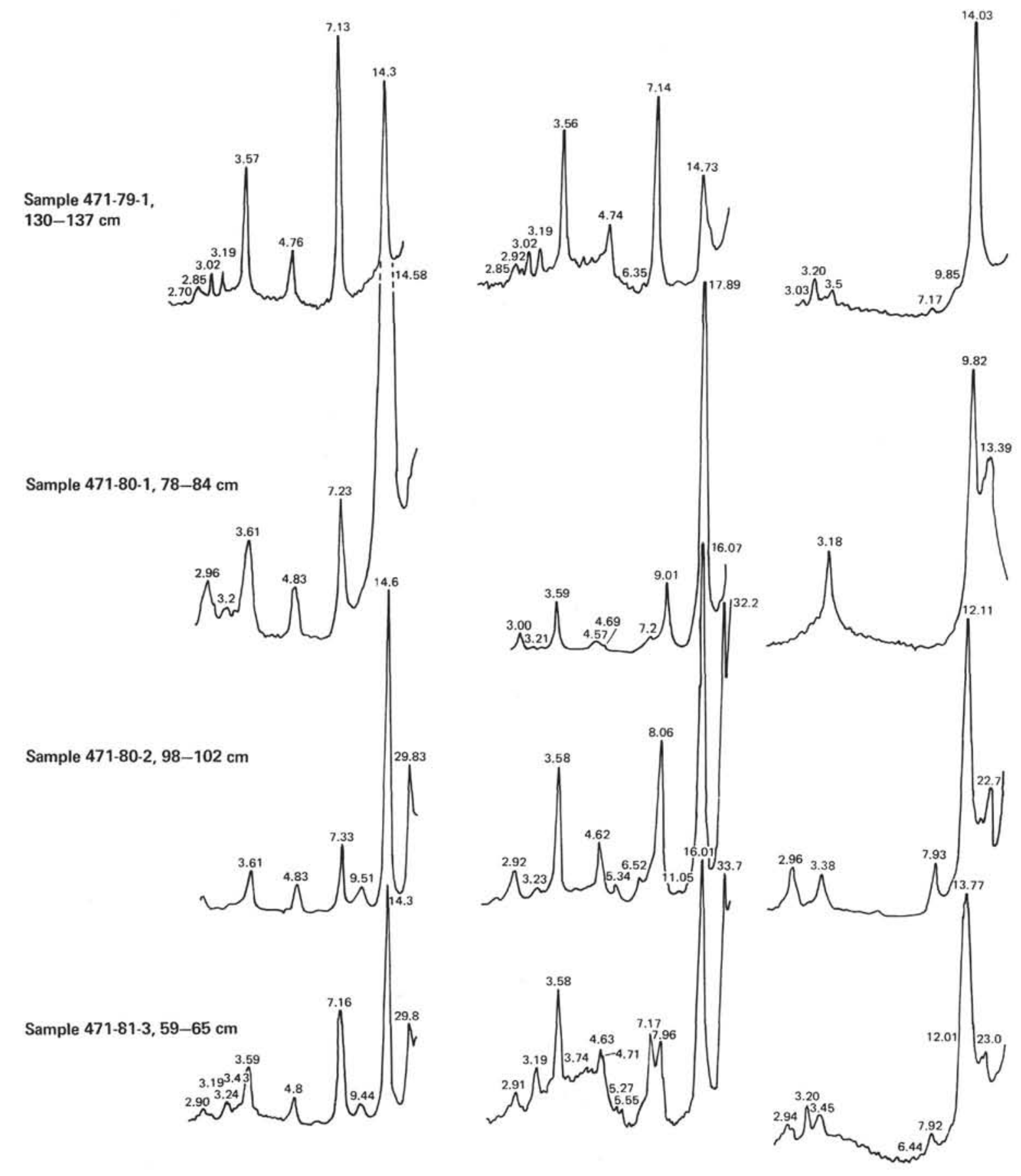



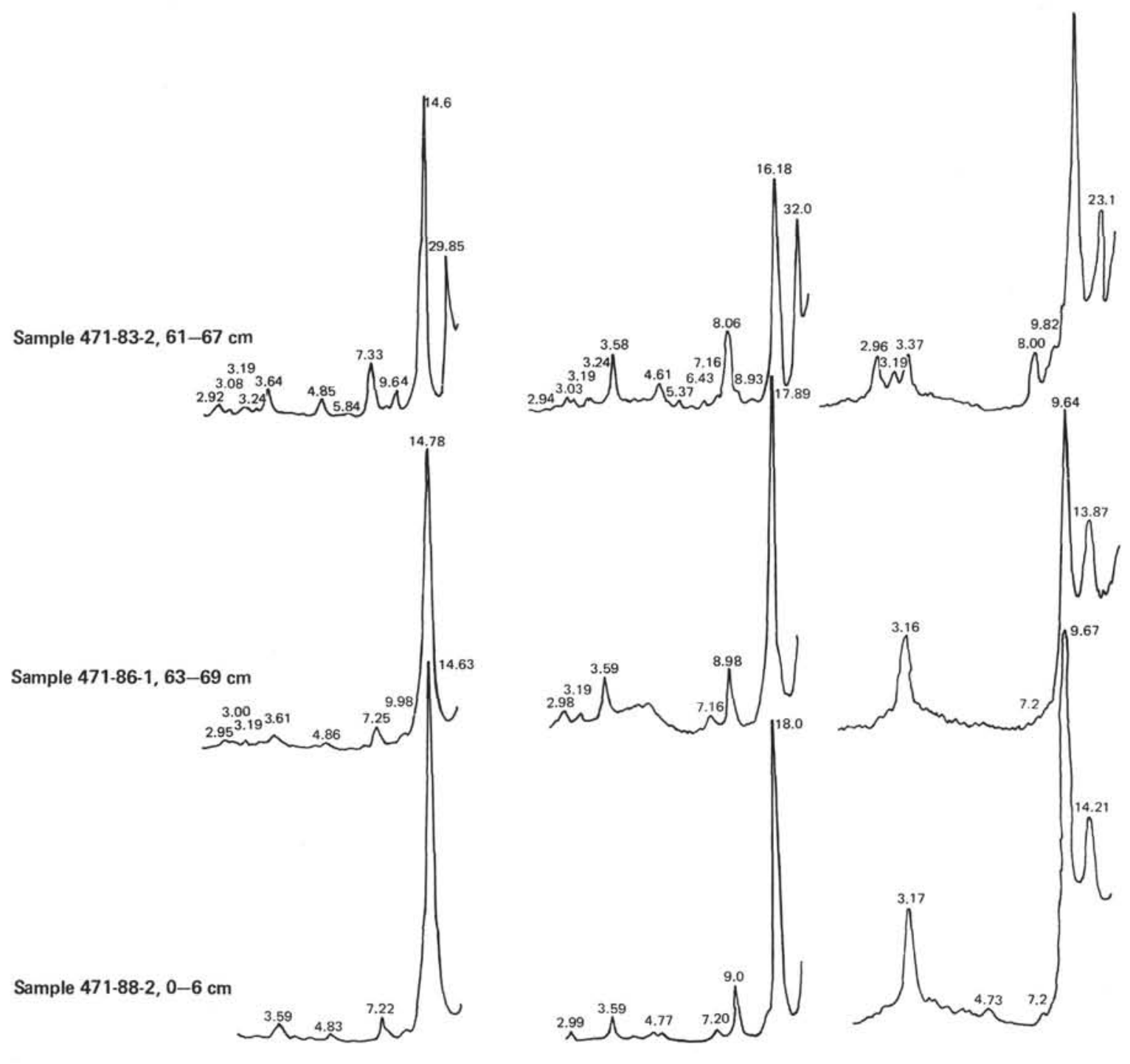

B

c

Figure 15. Diffractograms of the clay fraction from altered dolerites in Hole 471. A. Air-dried sample. B. Sample saturated with glycerine. C. Sample heated at $550^{\circ}$. 

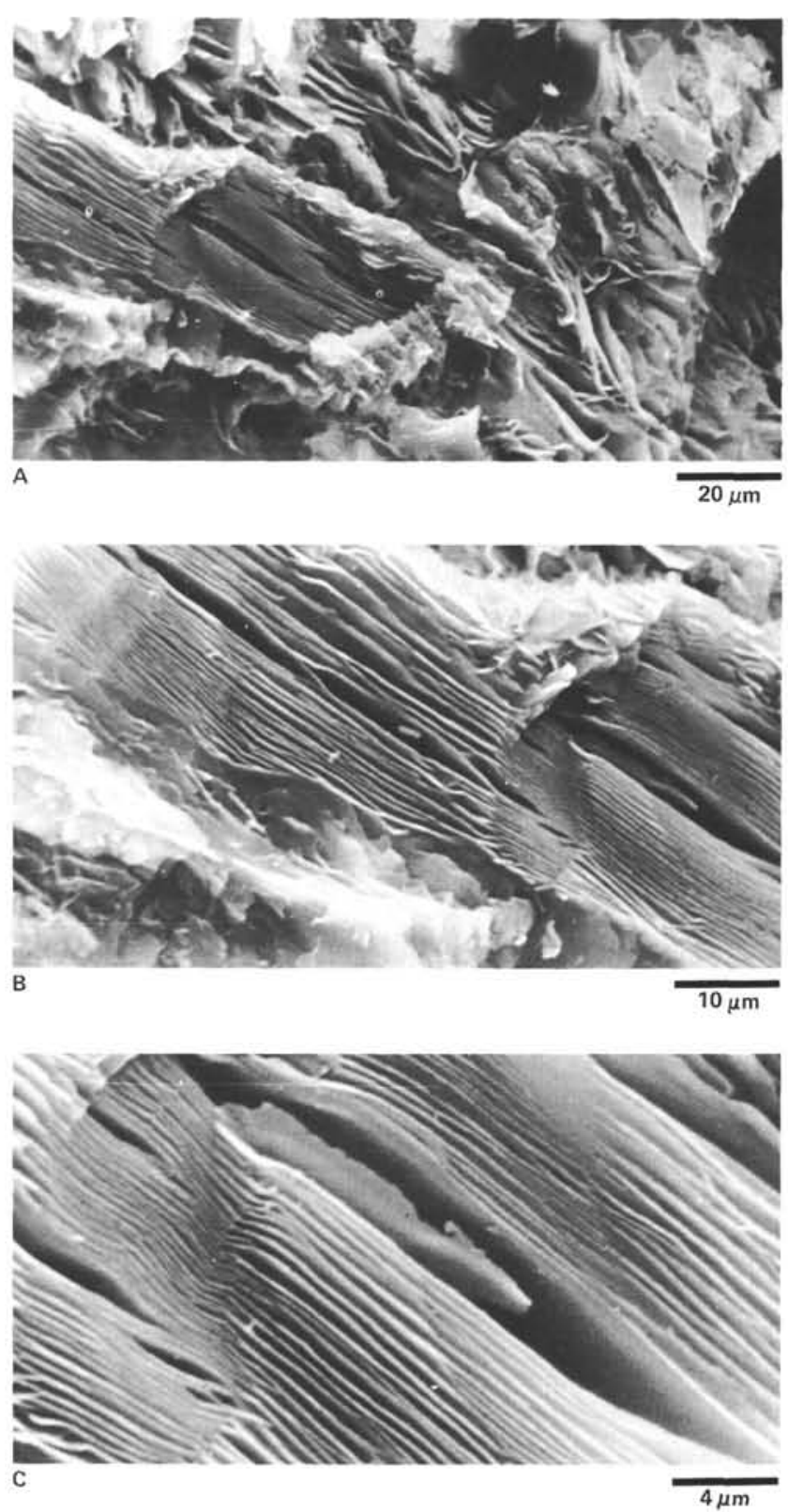

Figure 16. Scanning-electron microscope pictures of clay minerals (Sample 471-80-2, 98-102 cm); A., B., and C. show various magnifications, as indicated.

out their appreciable inflow. Higher $\mathrm{K}$ concentrations in some rocks are not always accompanied by strong secondary alterations of rocks. In altered rocks $\mathrm{K}$ is usually concentrated in smectites and sometimes in smectitic interlayers in corrensite and $\mathrm{K}$-feldspar.

\section{ACKNOWLEDGMENTS}

The authors are deeply grateful to the Director of the Geological Institute of the U.S.S.R. Academy of Sciences Academician A. V. Peive and to leaders of the DSDP Project Dr. D. G. Moore and Dr. M. N. A. Peterson for the chance to participate in DSDP Leg 63. It is a pleasure for us to note that the atmosphere on board ship during the leg was friendly and creative, thanks to Captain L. Dill and the officers and scientific-technical staff. We also thank our chemists G. F. Galkovskaya, N. L. Kalashnikova, G. I. Karaseva, and V. F.
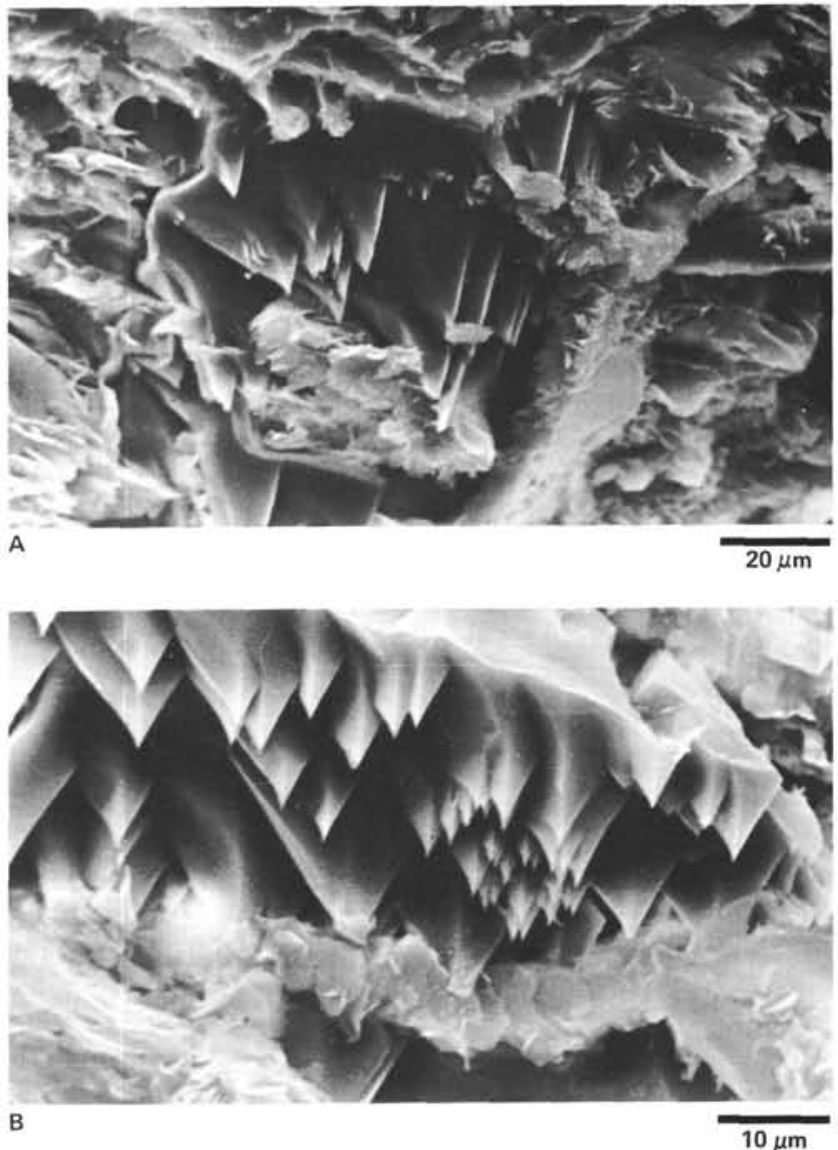

Figure 17. Scanning-electron microscope pictures of a chalcedonylike mineral (Sample 471-80-2, 98-102 cm); A. and B. show various magnifications.

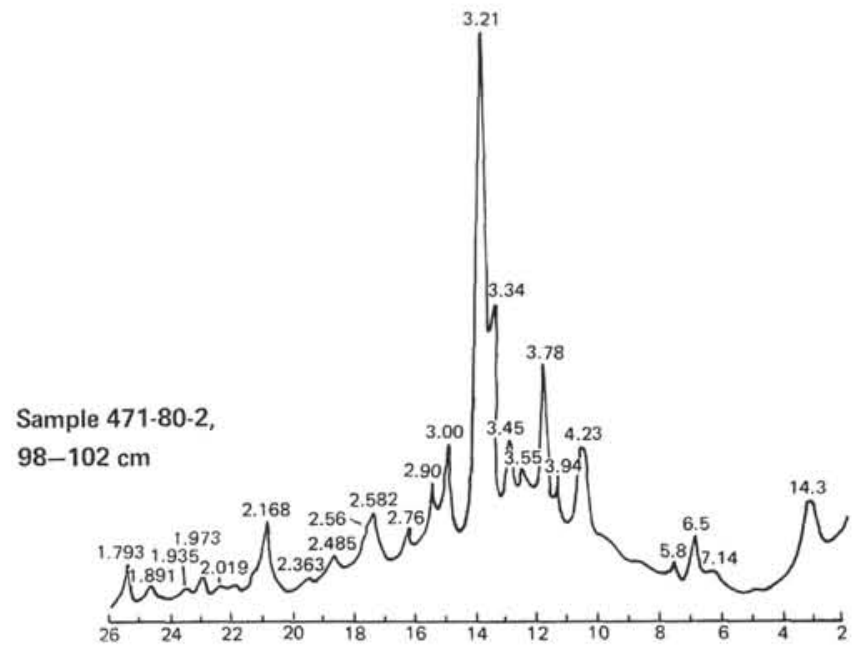

Figure 18. Diffractogram of K-feldspar from Sample 471-80-2, 98$102 \mathrm{~cm}$. (Fraction $0.01-0.1 \mathrm{~mm}$. Specific weight $2.5-2.6 \mathrm{~g} / \mathrm{cm}^{3}$.) 


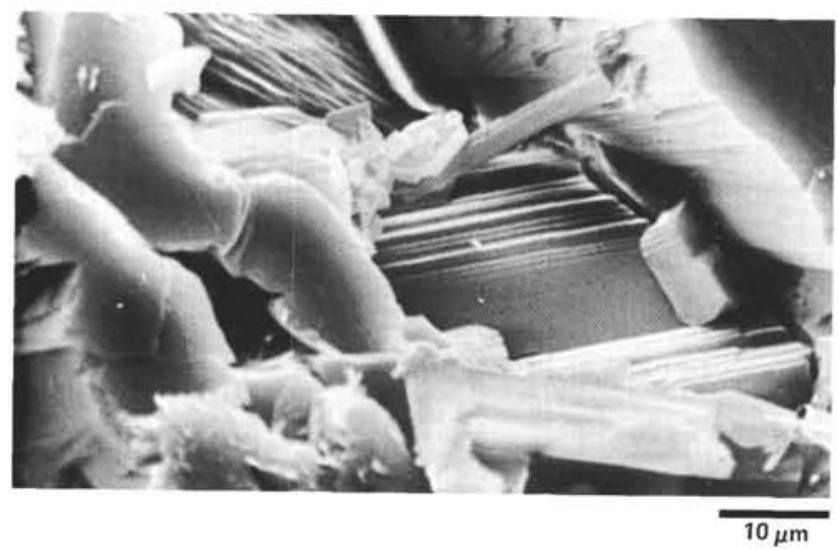

Figure 19. Scanning-electron microscope picture of chlorite (Sample $471-80-2,98-102 \mathrm{~cm})$.

Rychkova who carried out the analytical work and our colleagues Drs. V. A. Drits, B. A. Sakharov, E. M. Spiridonov, N. N. Pertsev, and V.

L. Rusinov for valuable consultations.

\section{REFERENCES}

Barth, T. F. W., 1969. Feldspar: London (Wiley-Interscience). , 1948. Oxygen of rocks: a basis of petrographic calculations. J. Geol., 56(I):50-60.

Chetverikov, S. D., 1956. Handbook for Petrochemical Evaluating. Publishing Office "Gosgeoltekhizdat," pp. 154-163.

Miyashiro, A., 1975. Classification characteristics and origin of ophiolites. J. Geol., 83:249-281.

Zolotarev, B. P., Choporov, D. Ya., and Voitov, G. I., 1979. Petrochemistry of basalts and distribution of organic gases: Holes 407 , $408,409,410 \mathrm{~A}, 411,412$, and 413, DSDP Leg 49. In Luyendyk, B. P., Cann, J. R., et al., Init. Repts. DSDP, 49: Washington (U.S. Govt. Printing Office), 727-744.

Zolotarev, B. P., 1979. Petrology of the basalts of the recent ocean in the connection of the tectonic position of them. Geotektonika, 1:22-35.
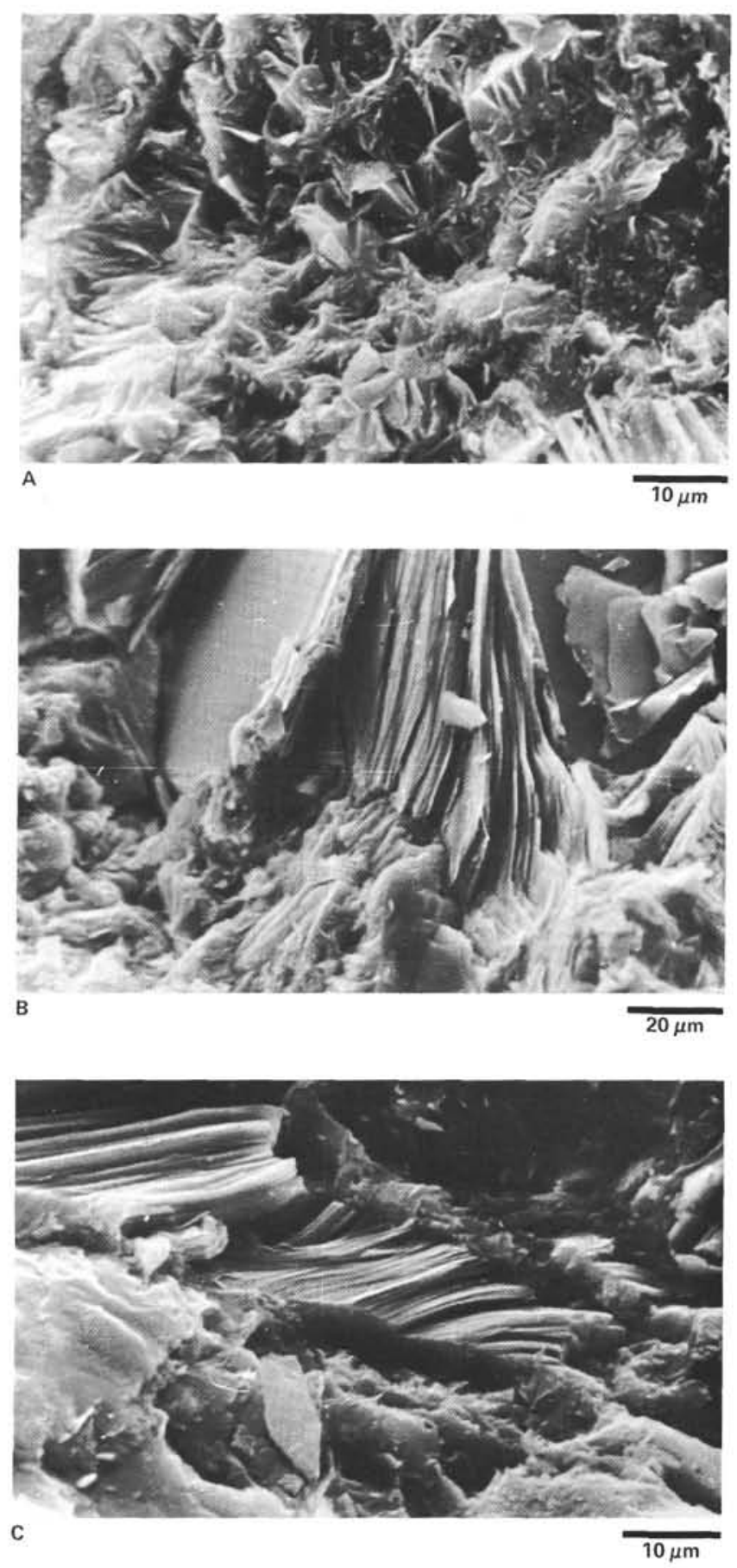

Figure 20. Scanning-electron microscope pictures of clay minerals of various forms (Sample 471-88-2, 0-6 cm). A. shows the coronated characteristic. B. and C. illustrate the filling of pores and fissures. 
Table 6. Balance of chemical elements in secondary alteration of dolerites in Hole 471 relative to Sample $469-42-1,117-120 \mathrm{~cm}$.

\begin{tabular}{|c|c|c|c|c|c|c|c|c|c|}
\hline \multirow{2}{*}{$\begin{array}{c}\text { Sample } \\
\text { (interval in cm) }\end{array}$} & \multicolumn{9}{|c|}{ Chemical Elements } \\
\hline & K & $\mathrm{Na}$ & $\mathrm{Ca}$ & $\mathrm{Mg}$ & $\mathrm{Fe}$ & Al & $\mathrm{Ti}$ & Si & $\mathrm{OH}$ \\
\hline $471-80-1,78-84$ & +1 & -9 & -12 & +32 & +24 & -24 & +7 & -54 & +83 \\
\hline $471-80-2,98-102$ & +14 & -27 & -58 & +65 & +18 & -44 & +4 & -117 & +276 \\
\hline $471-81-3,59-65$ & +22 & +12 & -26 & -13 & +3 & -25 & +4 & -38 & +134 \\
\hline $471-82-1,127-132$ & +21 & -9 & -30 & +21 & +13 & -33 & -1 & -61 & +172 \\
\hline $471-82-2,15-18$ & +21 & -13 & -36 & -22 & +13 & -34 & -1 & -61 & +183 \\
\hline $471-84-1,9-16$ & +1 & -5 & -3 & +36 & +13 & -29 & +3 & -47 & +93 \\
\hline $471-84-1,107-114$ & -2 & -16 & -1 & +23 & +18 & -37 & +3 & -65 & +124 \\
\hline $471-86-1,63-69$ & -2 & -21 & +22 & +17 & +5 & -2 & 0 & -56 & +90 \\
\hline $471-87-2,19-26$ & -2 & -24 & +19 & +28 & +5 & -12 & -1 & -63 & +111 \\
\hline $471-88-2,0-6$ & 0 & -45 & +1 & +124 & +25 & -42 & -1 & -78 & +98 \\
\hline
\end{tabular}
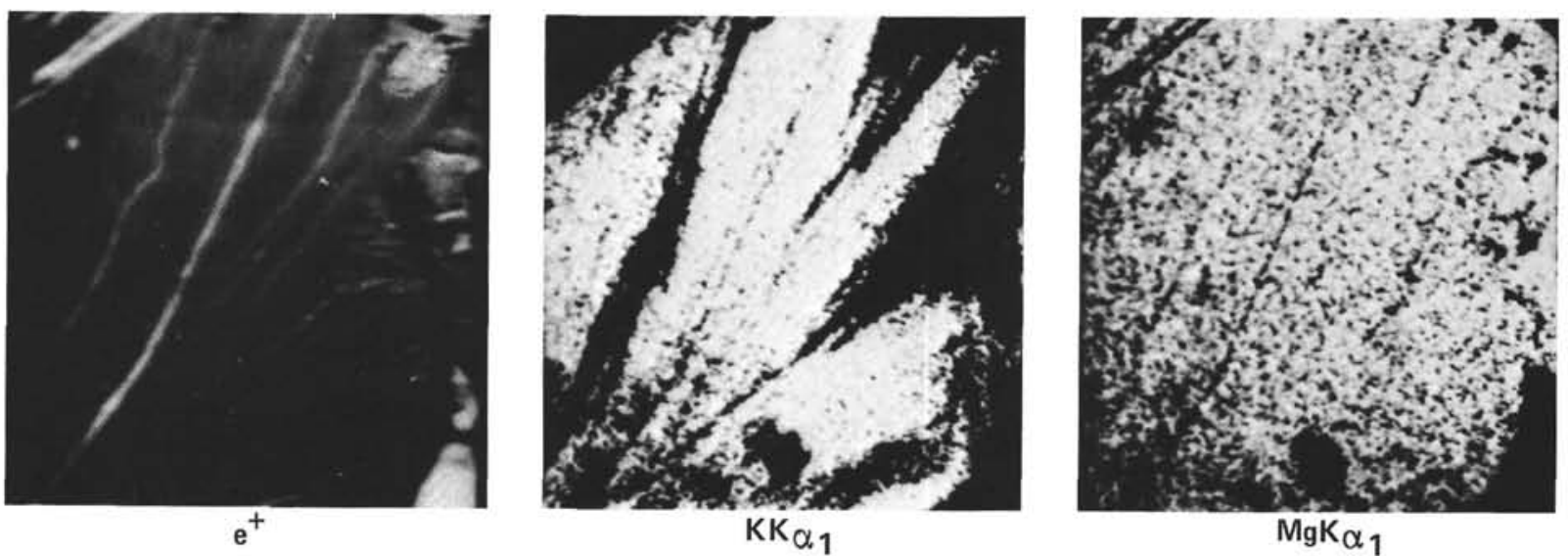

Figure 21. Results of microsounding of some aggregates of smectite in Sample 471-88-2, 0-6 $\mathrm{cm}\left(\mathrm{e}^{+}=\right.$scanning picture of the aggregate; $\mathrm{KK}_{\alpha_{1}}=$ distribution of $\mathrm{K} ; \mathrm{MgK}_{\alpha_{1}}=$ distribution of $\mathrm{Mg}$; scale $\left.=200 \mu \mathrm{m} \times 200 \mu \mathrm{m}\right)$. 